\title{
AN INTRODUCTION TO THE STUDY OF THE SOIL SOLUTION ${ }^{1}$
}

\author{
BY FRANK K. CAMERON
}

\section{The Soil}

The soil, or that part of the land surface of the earth adapted to the growth and support of crops, is a heterogeneous mixture composed of solids, gases and a liquid, and containing living organisms. There are present: mineral debris from rock degradation and decomposition; organic matter from the degradation and decomposition of former plant and animal tissues; the soil atmosphere, always richer in carbon dioxide and water vapor and possibly other gases than the atmosphere above the soil; living organisms, such as various kinds of bacteria and fungi, with the products of their activities, notably the "nitrogen carriers" and the enzymes; and finally the soil moisture, a solution of products yielded by the above components and in equilibrium or approaching equilibrium with the solids and gases with which it is in contact.

In its relation to crop plants, ${ }^{2}$ that part of the soil of immediate importance is the soil moisture. From this solution the plants, through their roots, draw all the material involved in their growth, except the carbon dioxide absorbed through their leaves. The soil solution is the natural nutrient medium from which the plants absorb the mineral constituents which have been shown to be absolutely essential to their continued existence and development. And from this solution plants sometimes absorb dissolved organic substances, but such absorptions are probably adventitious and incidental to the growth of the plant in a particular environment.

'Published by permission of the Secretary of Agriculture.

2 By crop plants are meant the ordinary green plants employed in agriculture. As is well known, the fungi as well as certain parasitic and saprophytic non-green seed plants obtain their nutriment in a very different way from ordinary green crop plants. 
Therefore, the study of the soil solution is of the first importance in the investigation of the relation of the soil to plant growth, and in the following pages there is given an outline of our present knowledge of the chemical principles involved, with such discussion of the physical and biological factors as is essential to an orderly presentation of the subject.

\section{Soil Management or Control}

From the practical point of view the problem of the soil in its relation to crop production is like the problem of the factory or of any other industrial endeavor, in that it is a problem of management or control. The soil possesses this distinction, however, that it is both the raw material and the factory. ${ }^{1}$ The processes involved are physical, chemical and biological, are always numerous and interdependent, and are never (speaking generally) exactly the same, so that each soil possesses marked individuality. No matter how soils may be classified, as for instance into provinces, series and types, ${ }^{2}$ the fact remains that the soil of the individual field has properties which give it a crop-producing power, an adaptation to a specific crop or crop rotation, or a responsiveness to cultural treatment, which can not be anticipated in

${ }^{1}$ According to S. W. Johnson-Some points of agricultural science, Am. Jour. Sci. (2), 28, $7 \mathrm{I}^{-85}$ (1859)-“"The soil (speaking in the widest sense) is then not only the ultimate exhaustless source of mineral (fixed) food, to vegetation, but it is the storehouse and conservatory of this food, protecting its own resources from waste and from too rapid use, and converting the highly soluble matters of animal exuviæ as well as of artificial refuse (manures) into permanent supplies."

${ }^{2}$ For definitions, see Soil Survey Field Book, 1906, Bureau of Soils, U. S. Dept. of Agriculture, pp. 15-24. On the ground that experience has shown that genetic classifications are the ones which have generally persisted and proved the most useful, objection might be made to the classification just cited. But a careful inspection of the results of the Soil Survey by the U. S. Department of Agriculture will show that while not categorically stating the fact, to all intents and purposes it has employed a genetic classification. This is exemplified by the fact that its delineation of soil provinces corresponds quite closely with the recognized physiographic provinces of the United States. See map accompanying Soils of the United States, by Milton Whitney, Bull. No. 55, Bureal of Soils, U. S. Dept. Agriculture, rgog. 
any other field. Consequently, there is no possibility of reducing soil management or agriculture to the state of an exact science. That is to say, scientific investigation of the problems involved cannot be expected to yield absolute results, although furnishing the best possible basis on which to form judgments. Therefore, soil management, like other agricultural practices, is an art, more or less well founded on scientific principles, perhaps, but susceptible to much higher development as the scientific principles involved become better understood.

Aside from such devices as greenhouses, wind-breaks, etc., which have a local application only, there are three general methods of soil control: tillage methods, such as plowing and harrowing; rotation of crops; and the use of soil amendments or "fertilizers."

Our knowledge regarding tillage methods is generally considered to be fairly satisfactory. The purposes are well understood, namely, to break up and "fine" the soil, to keep down weeds, and by forming mulches to decrease the loss of water by evaporation. Not much increase is being made in our theoretical knowledge of this subject, although mechanical improvements in the implements of tillage are being and will undoubtedly continue to be made.

Our knowledge concerning crop rotations is fairly extensive, but it is almost entirely empirical. Some at least of the purposes served by a rotation of crops are fairly well known, such as the elimination of weeds or lower types of parasitic growth associated with particular crops; the introduction of humus by a grass crop or a green manure crop, especially by the Leguminosae with their symbiotic Azobacteria; the improvement in the structure or arrangement of the soil particles by alternating deep-rooted and shallow-rooted crops; the avoidance of continually growing a crop in the presence of its own excreta, and products of decay, etc.; and lastly, economic and market considerations.

Our knowledge of fertilizers, in spite of a vast amount of work and an enormous literature, is still very meagre and it also 
is almost entirely empirical; and this because studies on the subject have been dominated for three-quarters of a century by one theory almost to the exclusion of any other. The exponents of this theory have generally assumed that the action of fertilizers is on the plant rather than on the soil, and is independent of other factors. That is, while it is admitted that other factors influence plant growth, it has been held that the effect of the fertilizer is not to modify the influence of the other factors but to directly influence the plant by increasing its food supply. As a consequence, it has also been generally assumed that the influence of fertilizers is additive, that is, the increase in yield of crop is proportional to the increase in fertilizer added, and the increase in yield produced by adding two fertilizers is the sum of the increases which would have been produced by each alone. In this form the theory is essentially a quantitative one, and fertilizer practice should be easily susceptible of control by chemical analyses. But the large mass of data obtained from plot experiments shows that fertilizer effects are not additive. Indeed, the addition of some one or more fertilizer constituent is sometimes followed by a decreased yield. For example, about 20 percent of the trials of fertilizers on soils growing corn and reported by the American State Experiment Stations showed a decreased yield. And furthermore, in spite of the quantitative character of the theory, and the numerous analyses of soils and of plants which have been made, there is yet lacking any authoritative method for determining in quantitative terms the fertilizer needs of a soil. That analytical methods have a very restricted value in indicating even qualitatively the fertilizer needs of the soil is evidenced by the fact that within the past few years a number of the State Experiment Stations have publicly announced their unwillingness to undertake them. ${ }^{1}$

${ }^{2}$ In this connection see: The texture of the soil, by L. H. Bailey, Cornell University Agr. Expt. Sta., Bull. No. IIg (I896); Suggestions regarding the examination of lands, by E. W. Hilgard, University of California, College of Agriculture, Circ. No. 25 (rgo6); Chemical analysis of soils, by William 
The common procedure has been to define some arbitrary percentage limit in the soil, below which the soil is supposed to require fertilizers. But the amount of fertilizer to be applied is suggested on the indefinite basis of "experience." Thus, Hilgard, in an interesting discussion of this subject, ${ }^{1}$ quotes Dyer as showing that "on Rothamsted soils of known productiveness or manurial condition, it appears that when the citric acid extraction yields as much as 0.005 percent of potash and o.oro percent of phosphoric acid, the supply is adequate for normal crop production, so that the use of the above substances as fertilizers would be, if not ineffective, at least not a profitable investment." Hilgard himself sets limits as determined by strong hydrochloric acid digestion; thus a soil containing upwards of 0.45 percent potash $\left(\mathrm{K}_{2} \mathrm{O}\right)$ does not need this substance as a fertilizer, while one containing below 0.25 percent does need it at once, and intermediate percentages indicate that potash fertilizers would probably be profitable; the corresponding upper and lower limits for phosphoric acid are set at 0.10 percent and 0.05 percent. But Hilgard points out that various things, such as the content of lime, or the texture of the soil, may materially alter these limits. In a very interesting set of experiments in which white mustard was grown in various soils, and these same soils diluted with various amounts of dune sand which had previously been extracted with strong hydrochloric acid, he found that the plants did best when the soils had been diluted with four times their weight of the extracted sand. This was the case even with a pulverulent

P. Brooks, Massachusetts Agr. Expt. Sta., Circ. No. II (1907); Testing soils for fertilizer needs, by F. W. Taylor, New Hampshire Agr. Expt. Sta., Circ. No. 2 (I908); The uses and limitations of soil analysis, by J. T. Willard, The Industrialist, Kansas State Agricultural College, 34, 291 (I908); Soil analysis, by Wm. Frear, Pennsylvania Agr. Expt. Sta., Chem. Circ. No. I; How to determine the fertilizer requirements of Ohio soils, by Chas. E. Thorne, Ohio Agr. Expt. Sta., Circ. No. 79 (1908); Concerning work which the station can and cannot undertake for residents of the state, by Joseph L. Hills, Vermont Agr. Expt. Sta., Circ. No. 3 (I909).

${ }^{1}$ Soils, by E. W. Hilgard, 1906, p. 339, et seq. 
sandy loam; and with a black adobe, the best results were obtained when the diluted soil contained but o.I5 percent potash $\left(\mathrm{K}_{2} \mathrm{O}\right)$ and 0.04 percent phosphoric acid $\left(\mathrm{P}_{2} \mathrm{O}_{5}\right)$. It also appears that Hilgard regards soil analyses of value only in the case of virgin soils or soils which have long been out of cultivation, and in common with other authorities, he fails to point out how to determine the amount of fertilizer needed by lands.

It is clear, therefore, that the principles underlying the practice or art of soil management and crop rotation are in a state of development far from satisfactory, and scientific methods of soil control are yet wanting. ${ }^{1}$ Recent activities in soil investigations, however, justify the hope that much improvement is to be anticipated, and the application of the modern methods of physical, chemical, and biological research to the soil problem promises a sure and probably rapid advance in this branch of applied science.

\section{Soil Analysis and the Historical Methods of Soil Investigation}

Owing to the labors of Davy, Boussingault, de Saussure, Liebig, Sachs, Knop, Salm-Horstmar, and other scarcely less distinguished savants, it has been clearly shown that growing plants need certain mineral elements in order to maintain their metabolic functions, and that these mineral elements can be obtained, under normal conditions, from the soil. All subsequent investigation has confirmed these statements and they can now be accepted as facts with as much assurance as any known law of nature.

1 It should, of course, be borne in mind that soil factors are not the only ones in crop production. Control by seed selection, breeding of standard types of plants, etc., may be, and probably is, more highly developed than control by soil factors. The same might possibly be claimed for moisture supply in irrigated areas; but on the other hand, such factors as the bacterial and lower life prot cesses in the soil are generally under little or no control, and as a rule the amount and distribution of sunlight under none at all. A notable effort has been made in the last case with shade-grown tobacco (see Bulletins Nos. 20 and 39, Bureau of Soils, U. S. Dept. Agriculture) and a few cases are known where shade-crops are employed, but not in general agriculture. 
The determination and formulation of these two fundamental facts came at a time when analytical chemistry was being rapidly developed and was finding wide and useful applications in numerous fields of activity. It was natural, therefore, that analytical chemistry should be enlisted in this new field of work, obviously of the first importance to the welfare of mankind. It was early found, however, that the chemical analysis of a soil fails to explain its relative productivity. In other words the content of a soil with respect to potash, phosphoric acid, or other mineral plant-food constituent, bears no necessary relation to its crop-producing power. Many cases were found where one soil "analyzed well" but did not produce as large a crop as another soil which "analyzed poor." To meet this difficulty a subsidiary hypothesis was brought forward, which rapidly gained general acceptance, although lacking experimental support.

This hypothesis supposes that the mineral constituents of the soil are present in two different chemical conditions or distinct kinds of combinations, one of which readily gives up its constituents to growing plants, while the other does not; and the constituents have, therefore, been called respectively "available" and "non-available." It would appear from his writings that Liebig regarded this distinction as applying to the "absorbed" or "adsorbed" mineral matter; that is, on the one hand the material held. in or upon the soil grains by surface forces, and on the other the chemically combined constituents in the minerals themselves. We know that Liebig was much impressed by the absorption experiments of Way, and himself did much work in this field. ${ }^{1}$ But the great body of soil investigators has evidently held to the opinion that there are two general classes of minerals in the soil. Some have held that the "available" potassium is held in zeolites or "zeolitic minerals an interesting example

1 Way was misled, as we now know, in considering the results of his absorption experiments with soils as merely metathetical reactions; see $\mathrm{Ab}$ sorption by soils, by Harrison E. Patten and William H. Waggaman, Bull. No. 52, Bureau of Soils, U. S. Dept. Agriculture, 1908. 
often cited being glauconite or "green sand marl" which sometimes contains phosphorus as well as potassium;"1 in minerals which are easily broken down by alkaline solutions, as by sodium carbonate solutions or ammonia; or in minerals which are easily broken down by organic acids supposedly excreted from the roots of growing plants, or formed by the decay of plant tissue. ${ }^{2}$

With the advent of this idea of a distinction between the available and non-available mineral plant-food elements in the soil, came attempts to distinguish them by analytical methods. Of these we now have a bewildering array, most of them frankly empirical. For instance, Hilgard, in his classical investigation of the cotton soils for the Tenth Census, treated his soil samples with an excess of hydrochloric acid, evaporated to dryness, extracted with water, and regarded the extracted mineral constituents as available. In Germany, a method similar to Hilgard's is now commonly used, while in France nitric acid is preferred generally because it is supposed to have peculiar solvent powers on soil phosphates. In the United States the "official method" of the Association of Official Agricultural Chemists is to keep ro grams of the soil in contact with IoO $\mathrm{cc}$ of a solution of hydrochloric acid (specific gravity I.I I5) at the boiling point of water for exactly ro hours. In England the popular method is that proposed by Dyer, namely, to treat the soil with a I percent citric acid solution, this strength of solution being supposed at one time to represent the average acidity of root sap. Maxwell, in

1 The formation of zeolites in the soil has often been assumed, but has not yet been proven; see, Rocks, rock-weathering and soils, by George P. Merrill, 1906, .p. $3^{63}$.

2 The classic experiments of Sachs, in producing etchings on marble slabs, and the etchings observed occasionally on rock surfaces are the proofs universally cited. The experiments of Czapek, who substituted slabs of aluminum phosphate and other substances for the marble, and those of Kossowitch, show that the action can be accounted for more satisfactorily and reasonably as due to dissolved carbon dioxide. In fact such etchings can be produced on marble slabs by laying platinum wires upon them and covering with moist soil, or cotton, or mats of filter paper; see Bull. No. 22, p. I4, and Bull. No. 30, p. 4I, Bureau of Soils, U. S. Dept. Agriculture. 
Hawaii, and afterwards in Australia, claimed good results for the extraction of the soil with a I percent solution of aspartic acid, this acid being employed on the erroneous ground that the organic acids of the soil are amido acids, and that these are the effective agents in dissolving the soil minerals and rendering their constituents "available."

The Kentucky Agricultural Experiment Station favors an $\mathrm{N} / 5$ nitric acid solution, ${ }^{1}$ but does not recommend its use for soils of other localities, while in a contiguous state, the Tennessee Station favors the "official" method." Many other methods have been proposed, but the foregoing are typical and sufficient to illustrate the present status of soil analysis.

It is clear that these several methods must give differing results. And it is not clear that any one of them is to be preferred to the others for any other reasons than analytical convenience. There is no reason to expect that the proportion of solvent to soil required in these methods bears any relation whatever to the mechanism of absorption by plant roots. And the attempts to simulate the properties of plant sap in some of these solvents are obviously illogical, for the plant sap does not come in contact with the soil grains, except through an accidental destruction of the plant.

Naturally, comparisons were attempted between the amounts of the mineral constituents extracted from a soil by these various solvents and the amounts taken up by crops growing on the soil. It was found, however, that the amount of any given mineral constituent extracted from the soil by a solvent is not, generally, the same as that taken up by the plant. Moreover, the ratio of one constituent to another in the extract bears no definite relation to the ratio of these constituents in the plant. Nevertheless many efforts were made to establish "factors." For instance, the percentage of potash extracted from the soil of a field by hydrochloric acid is some multiple of the percentage removed by a wheat crop;

${ }^{1}$ Soils, by A. M. Peter and S. D. Averitt, Bull. No. I26, p. 66 (I906).

2 The soils of Tennessee, by Charles A. Mooers, Bull. No. 78, p.49 (Igo6). 
it was sought to determine this multiple, assuming it to be a definite ratio and a natural constant, and it was designated as the potash factor. But there is a different factor for phosphorus, another for calcium, and still others for each and every constituent. The factors found for a soil from one area generally do not hold for a soil from another area. Again, different factors obviously must be used for different crops. And, finally, the whole scheme becomes hopelessly absurd when it is realized that the same crop will yield widely varying ash analyses, depending upon the cultural methods employed, the judicious selection of seed, the amount and distribution of rainfall and sunlight, and possibly other agencies, all of which affect the growth and absorptive functions of the plant to as great an extent as does the particular soil upon which it may be growing.

Moreover, from the purely analytical point of view the situation is no better. For instance, the addition of potassium in the amounts usually employed in ordinary fertilizer practice generally does produce a noticeable effect on the yield of crop. The average application of potash $\left(\mathrm{K}_{2} \mathrm{O}\right)$ is certainly less than $50 \mathrm{lbs}$. to the acre. It is customary to consider the surface foot of soil as the region affected by the fertilizer, and an acre foot in good moisture condition weighs about 4,000,000 1bs. To be conservative, let it be assumed that 60 lbs. of potash have been added to 3,000,000 tbs. of soil. The official method of the Association of Official Agricultural Chemists calls for the determination of the potash in 2 grams of soil, which on the basis of the present assumption calls for the estimation of an added amount of 0.00004 gram of potash or 0.002 percent. Taking as an example the report of the Association of Official Agricultural Chemists for I $895^{1}$ there are given the following results obtained independently by a number of analysts, on soils which had presumably been sampled by the referee with all possible care:

I Proceedings of the Twelfth Annual Convention of the Association of Official Agricultural Chemists, Bull. No. 47, Division of Chemistry, U. S. Dept. Agriculture, p. 36 (1896). 
Potash Calculated as Percent of the Fine Dried Earth

\begin{tabular}{|c|c|c|c|c|c|c|c|c|}
\hline \multirow{2}{*}{ Analyst } & \multicolumn{2}{|c|}{ I } & \multicolumn{2}{|c|}{2} & \multicolumn{2}{|c|}{3} & \multicolumn{2}{|c|}{4} \\
\hline & Percent & Var. & Percent & Var. & Percent & Var. & Percent & Var. \\
\hline A & 0.359 & 0.044 & 0.154 & -0.002 & - & - & - & - \\
\hline B & 0.345 & 0.030 & O. I I 2 & -0.044 & 0.380 & $0.05^{I}$ & 0.104 & -0.050 \\
\hline C & 0.354 & 0.039 & 0.235 & 0.079 & 0.396 & 0.067 & 0.225 & $0.07 I$ \\
\hline D. & 0.260 & -0.055 & - & - & - & - & - & - \\
\hline $\mathrm{E}$. & 0.373 & 0.058 & 0.179 & 0.023 & $0.3^{6} 5$ & 0.036 & o. I75 & $0.02 \mathrm{I}$ \\
\hline$F$ & 0.210 & -0.105 & 0.130 & -0.026 & 0.220 & -o. I09 & 0.109 & -0.045 \\
\hline & 0.304 & $-0.01 \mathrm{I}$ & 0.125 & $-0.03 I$ & 0.286 & -0.043 & o. I 58 & 0.004 \\
\hline Mean. & 0.3 I 5 & - & 0.156 & $1-1$ & 0.329 & - & O. I 54 & 一 \\
\hline
\end{tabular}

Not only do the individual determinations show differences farr in excess of 0.002 percent, but the differences between each individual reading and the mean is greater than 0.002 percent, so that it is evident from these results that the analytical procedure fails to recognize appreciable amounts of the so-called available plant foods. Consequently the "acid digestion" of a soil fails of the purpose for which it was designed, and it is one of the mysteries of chemical history that so much time and energy have been devoted to such a hopeless quest.

This state of affairs is the more surprising when the limitations of the analytical procedure are considered. The data tabulated above indicate that the analyses were made with an exactness that justifies a statement to three decimal places, that is, to three significant figures; and in fact, as was shown, such is necessary if the figures are to have any significance regarding fertilizer applications. It is obvious that the analysis of a finely pulverized definite mineral or rock is less subject to error than a sample of soil sifted through a $2 \mathrm{~mm}$ mesh. Yet the U. S. Geological Survey commonly reports its analytical data to only two decimal places. What variation may be expected in duplicate determinations by the same analysts it is difficult to say, for such duplicates are not 
commonly published. ${ }^{1}$ In spite of the widespread view that the chemical analysis of a soil is a statement of great accuracy, it is improbable that as usually determined the potash content is correct to three or even two significant figures; it is also doubtful if the phosphoric acid content is correct to even one significant figure, if the total amount is below o. I percent of the soil. That these determinations have a higher accuracy than here stated is not shown by an inspection of the literature including the fairly numerous results reported in the annual Proceedings of the Association of Official Agricultural Chemists.

It was early felt by some investigators that soil analyses were unsatisfactory for studying the relation of the soil to the food requirements of a crop, and a second method was devised, namely, the growing of a crop, and determining the amount of mineral constituents removed from the soil by analyzing the ash of the crop. From the point of view of practical soil management this procedure involves the serious difficulty of being first obliged to get the crop before determining what must be done to best get it. It apparently has the scientific advantage of directness in determining the mineral needs of the plant from the plant itself. If these needs were constant, the advantage would be real, but as already mentioned, one and the same plant may have a very different ash content as the result of different cultural methods, different climatic and seasonal factors, as well as different soils. Generally, a poor crop has a higher percentage of ash content than a good crop, and sometimes the poor crop may remove from the soil more in absolute amounts of some one or other of the ash constituents than does the good crop. The ratio of the ash constituents is by no means constant for any one crop, and of course varies

${ }^{1}$ See: On the interpretation of mineral analyses, by S. L. Penfield, Amer. Jour. Sci., (4), Io, 33 (1900); The analysis of silicate and carbonate rocks, by W. F. Hillebrand, Bull. No. 305, U. S. Geol. Surv., r907; Manual of the chemical analysis of rocks, by H. S. Washington, 1904, p. 24; Ueber Genauigkeit von Gesteinanalysen, von M. Dittrich, Neues Jahrbuch für Mineralogie Geologie und Palaeontologie, 2, 69 (1903). 
with different crops. ${ }^{1}$ Finally, it is now known that the amount of the several mineral nutrients which a soil must furnish to a crop in the earlier stages of growth is greater than the crop contents at maturity ${ }^{2}$ consequently an analysis of the ripe crop would not indicate the plant's drain upon the soil at all growing periods. So that, while ash analyses have taught some important things concerning plant growth, they have of necessity failed as guides or criteria of the cropproducing power of a soil, its fertilizer requirements, or its content of "available" plant-food.

-A third method of soil investigation, also essentially analytical in character, is the plot or pot test. The difference between a plot or pot experiment is mainly one of size, although it is claimed, and with a certain amount of justice, that the plot experiment more nearly approximates actual practice, and should be given a somewhat different consideration than the more readily controlled pot experiment. Here again it has to be considered that seasonal factors and factors other than the soil play a relatively large part in the production of the crop, so that conclusions regarding the productivity of a soil can not be drawn from one season's crop. Also, nowadays it is recognized generally that continuous growing of one crop is an incorrect practice, and a rotation should be followed and repeated several times before conclusions regarding the productivity of the soil are justified. If, however, the rotation has been well managed, the cultivation, fertilizing and soil management generally been well done for sixteen, twenty or more years, the soil has materially changed, and there can be no assurance that the treatment then best for it, is that which was best at the beginning of

1 For a brief but comprehensive discussion of ash analyses see, The ash constituents of plants, etc., by B. Tollens, Expt. Sta. Rec., I3, 207-220, 305-317 (1901-02).

2 Über die Nährstoffaufnahme der Pflanzen in verschiedenen Zeiten ihres Wachstums, von Wilfarth, Römer und Wimmer, Landw. Vers. Sta.; 63, I-70 (1905); Plant food removed from growing plants by rain or dew, by J. A. Le Clerc and J. F. Breazeale, Year Book, U. S. Dept. Agriculture, I908, p. 389-402. 
the experiment. Therefore the method throws no certain light on the productive power of the soil, or the availability of its mineral plant-food constituents. Although much has been learned from plot experiments, and especially from the better controlled pot experiments, they are inadequate to meet the fundamental problem of the relation of the chemical characteristics of the soil to its crop-producing powers.

\section{The Plant-Food Theory of Fertilizers}

The guiding principle in soil investigations for about three-quarters of a century and until the past few years has been the assumption that the principal function of the soil is to furnish mineral nutrients to the plant, and that, to supply a lack in the soil, fertilizers are added because of the mineral plant nutrients they contain.

This theory has apparently much to support it. It is attractively simple. It will be shown later, however, that this very simplicity is an argument against its validity.

Those substances which experience has shown to be useful soil amendments usually contain one or more of the constituents necessary to plant metabolism, commonly phosphorus, potassium, nitrogen or calcium. Fertilizers do not always produce increased yields of crops, but it has been usual to consider bad results as due to other more or less extraneous causes. Moreover, as will appear later, crop yield is as strongly affected by some substances containing no mineral plant nutrient as by ordinary fertilizers. Again, the plant-food theory has been apparently confirmed by the popular misconception that crop yields are decreasing. Government statistics, however, indicate very positively that crop yields are increasing in Europe as well as in America, more in areas where the acreage is stationary than in areas where the acreage is increasing, and in areas where fertilizers are not used as well as in areas where they are used. Analyses of European soils which have been cropped for centuries' show no characteristic differences from the newer soils of the 
United States. ${ }^{1}$ It is true that, from bad management or other causes, individual fields where crop production has fallen off are not uncommon. But that such a condition is general or that it can be associated generally with a decreased content in the soil of any particular mineral substance or substances, is a conclusion not sustained by the available data.

The plant-food theory of fertilizers must now be regarded as entirely insufficient. Granting that it has been useful in the past and has occasioned much valuable work, it seems to have reached the point which another simple and temporarily useful theory, the phlogiston theory of combustion, reached shortly before the plant-food theory of fertilizers was evolved. Just as the phlogiston theory passed, away when the elementary nature of oxygen was established and Lavoisier taught the scientific world how to use the balance, so the plant-food theory of fertilizers must pass with increasing knowledge of the relation of soil to plant and the application of modern methods of research to the problem.

\section{The Dynamic Nature of Soil Phenomena}

In soil investigations, until recently, the assumption has been made, more or less explicitly, that any given soil mass, as for instance a field, remains fixed or in place indefinitely. It has been admitted, of course, that some physical, chemical and biological processes might be taking place in the soil, but these have been regarded as relatively unimportant in their effects upon the soil mass in toto. It has been assumed that the only important change taking place in the soil is a loss of mineral plant nutrients, partly by leaching, partly by removal in the garnered crops. In other words, the soil has been regarded as a static system. This is a fundamental error. In studying the soil as a medium for crop production, we must consider the plant itself, or at

${ }^{1}$ A study of crop yields and soil composition in relation to soil productivity, by Milton Whitney, Bull. No. 57, Bureau of Soils, U. S. Dept. Agriculture, I909. 
least that part of the plant which enters the soil, namely, the root; the solid particles of the soil; the soil water, or the aqueous solution from which the plant draws all the materials for its sustenance, excepting the carbon dioxide absorbed by its aerial portions; the soil atmosphere; the biological processes taking place. The one common characteristic of all these things is that they are continually in a state of change; therefore the soil problem is essentially dynamic.

The root of a growing plant is always moving. ${ }^{1}$ The amount of motion may be small or large, depending upon the surrounding conditions or attendant circumstances, but cessation of motion means the death of the root. This becomes evident from a consideration of the mechanism of root growth. The living root absorbs and excretes water and dissolved substances through a restricted area just back of the root tip or the tips of the root hairs. While absorption is taking place, however, there is a deposition of denser material over the absorbing area, or "root corking." But coincident with the corking process, the tip is pushed forward between the soil grains into the nutrient medium, new cells are formed and a new absorbing surface continually brought into functional activity. A failure of the plant root to move forward in this way would mean a reabsorption of root effluvia with harmful consequences to the plant, or a corking over of the root without further formation of absorbing surface with consequent cessation of its functioning. This would mean the inevitable death of the root, and, if general, of the whole plant. It is clear, therefore, that root

I In order to penetrate the soil, a living root must be capable of exerting large pressirures, and indeed, the magnitude of these pressures has been determined for some cases. See, for citations of the literature, Pfeffer, Plant Physiology, translated by Ewart, 1903, Vol. 2, p. 124 et seq. But it can not be doubted that, in general, root movement is much facilitated and perhaps directed by movements among the soil particles. As the absorbing tip of the root removes film water from the adjacent soil grains, there is a necessary rearrangement of these grains with a shrinking away from the tip, which then moves forward by taking advantage of the movements among the soil grains. 
penetration and absorption of plant nutrients is essentially dynamic.

The solid components of the soil are always in motion. Every soil, no matter how flat the area or how well protected by vegetal covering, suffers some translocation of soil material through rains, as is evidenced by suspended material in the run-off waters. On hillsides this is shown by the soil accumulating on the "up" sides of fences, especially stone fences. In the aggregate this movement is probably quite large everywhere. It is manifestly so in the watersheds of many of the world's important rivers as shown by their muddy waters and the formation of deltas, sometimes of great area and agricultural importance.

With the saturation or approach to saturation of the surface soil the particles are more easily moved among themselves. by an extraneous force. It is very rarely that the surface of a field is a dead level. Consequently when the soil is wetted, the gravitational force on the individual soil grains produces a more or less pronounced "creeping" effect down hill. On decided slopes this soil creep is believed to be of great importance in connection with soil erosion. ${ }^{1}$

As important as is the translocation of material by water, quite as important probably is that produced by the winds. These are blowing all the time, uphill as well as

${ }^{1}$ Soil erosion is undoubtedly one of the greatest economic problems of the time, and yet there is scarcely any subject about which there are current so many popular misconceptions. In the rivers and to those who use the rivers the water-borne soil material is an unmitigated nuisance, save probably to the few cultivators of low-lying lands who flood their fields for the sake of the silt deposited. To the upland farmer, however, erosion is not only a necessity of natural conditions which can not be avoided entirely, but under proper control it may be even a blessing. The scalded and gullied hillsides, a trial and unnecessary disgrace to the owner, are probably not the main sources of the material which finds its way to the river. On the contrary, what are regarded usually as well-tilled fields supply the greater part of the suspended material in the rivers. The problem of erosion on the farm is not merely to check gullying and scalding, and deepening of stream heads, but to so adjust both cropping system and cultural methods as to secure a reasonable translocation of surface soil material with a minimum contamination of the neighborhood streams. See Man and the earth, by Nathaniel Southgate Shaler, 1905 . 
down, and their range of action is thus far wider than is that of rain and flood. The effectiveness of the wind as a translocating agency is seldom realized or even suspected by the layman, although it is commonly known that the air always contains some dust, and dust storms are familiar phenomena. That soil material can be carried long distances is certain, however, as for instance the sirocco dust, often carried from the Sahara over Europe. ${ }^{1}$ Dust carried high into the air by volcanic eruptions sometimes travels enormous distances, as in the case of the eruption of Krakatoa, when such material is reported to have traveled thousands of miles, and volcanic dèbris from the eruptions at Soufrière fell upon ships several hundred miles distant. Arctic explorers have reported the finding of wind-borne soil materials over the polar ice, and mountaineers have observed similar deposits on snow-capped peaks. Soil material on roofs and similar inaccessible places has been observed many times, and testifies to the continual activity of the wind. The burial of objects even of considerable size by wind-borne soil gives like testimony.

Measurements of the amount of action of wind in translocating soil material are rare and probably have a qualitative value only. But Udden ${ }^{2}$ in what appears to be a conservative calculation, finds "the capacity of the atmosphere [over the Mississippi Valley] to transport dust is rooo times as great as that of the [Mississippi] River." The wind seldom is carrying anything like so great a load as it is capable of carrying. That is, the wind in its attack upon the land surface does not ordinarily obtain so large an amount of material capable of being wind-borne as it is possible for the wind to carry when suitable material is artificially provided. It should be remembered that, speaking generally, the velocity

1 For a comprehensive discussion of wind as a translocating agent, see: The movement of soil material by the wind, by E. E. Free, Bureau of Soils, Bull. No. 68, U. S. Dept. Agriculture.

2 Erosion, transportation and sedimentation performed by the atmosphere, by J. A. Udden, Jour. Geol., 2, 3r8-33r (1894). 
of the wind is lower just at the surface of the ground than at heights above, and it is necessary to get the soil material above the surface before the wind can exercise its full efficiency as a carrying agent. Moreover, wind-borne material is constantly being deposited as well as being removed from the land surface. It is evident, however, that this movement of soil material by winds is very great, and there is no reason to believe that it is of any less importance in other areas than in the Mississippi Valley. It is also evident that the individual grains in any surface soil of any particular field or area are continually and more or less rapidly changing, and the farmer is not dealing to-day with just the same soil complex he faced a few years back, or will face a few years hence.

But besides the movements of the solid components of the soil by translocating agencies, other movements are constantly taking place. Whenever a moderately dry soil becomes wetted, it "swells up" until a certain critical amount of moisture is present above which there is a shrinking. But as a wet soil dries out again below the critical amount, there is again a shrinking. As it is always either raining or not raining, soils are always either getting wetted or are drying. Consequently the individual grains are continually moving about among themselves. A heavy object, such as stone, when left on the ground gradually sinks into it. ${ }^{1}$ Earthworms, burrowing animals and insects are continually at work in most arable soils. The action of frost in "heaving" a soil is familiar to everyone. Not so well known, however, is the fact that the apparently superficial cracks which occur to a greater or less extent in every soil, under drought conditions, are in reality quite deep, extending well into the subsoil. By the edges breaking off, and by wind-and water-borne material being carried in, considerable surface soil is thus brought into the subsoil. Through these various agencies, therefore, the

${ }^{1}$ On the small vertical movements of a stone laid on the surface of the ground, by Horace Darwin, Proceedings of the Royal Society of London, 68, 253-261 (1901). 
solid components of the soil are continually subject to much mixing; subsoil is becoming surface soil, and to some extent vice versa. An important result of these various processes is the bringing into the surface soil of degradation and decomposition products from underlying rocks. The processes involved are essentially dynamic. ${ }^{1}$

The soil solution is also a dynamic problem. When the rain falls on the soil, a part, the "run-off," flows over the surface and finds its way into the regional drainage; a part immediately evaporates into the air, and is designated as the "fly-off;" a third part, the "cut-off," enters the soil. ${ }^{2}$ The cut-off water penetrates the soil by way of the larger openings and interstices, and mainly under the influence of gravity. For convenience this downward-moving water is designated as "gravitational" water. It moves through the soil with comparative rapidity and a portion reappears elsewhere as seepage water, springs, etc. But with the return of fairweather conditions at the surface, there is increased evaporation and augmentation of the fly-off, and there is developed a drag or "capillary pull" on the water below. A large portion of the cut-off thus returns to the surface, mainly through films over the surface of the soil grains and in the finest interstices. ${ }^{3}$

The soil atmosphere is continually in motion, following with more or less decided lag the barometric changes in the atmosphere above the soil. Moreover, the chemical and physical processes continually taking place in the soil involve the absorption or the formation of free carbonic acid, and it seems probable that all rain water penetrating the soil gives up some oxygen to the soil atmosphere. The bacteria and lower life forms are necessarily undergoing changes con-

${ }^{2}$ It is clear that as the soil is continually changing through physical agencies, the chemical analysis of it can not be expected to furnish evidence as to the mineral constituents removed by crops or by leaching.

2 This terminology has been suggested by Dr. W J McGee.

${ }^{3}$ Leather, however, thinks that the water returns from only a limited depth, some 5-7 feet: see, The loss of water from soil during dry weather, by J. Walter Leather, Memoirs of the Department of Agriculture, Agricultural Research Institute, Pusa, India, Chemical series, I, 79-II6 (I908). 
tinually. In fact all components of the soil are continually undergoing, or are involved in, changes of one kind or another.

It is certain that investigation of the various motions and changes taking place in the soil is quite as important as investigation of the soil components, and that no clear idea of the chemistry of the soil can be obtained without it. The development of a rational practice of soil control is possible only when the soil is regarded from a dynamic viewpoint.

\section{The Film Water}

When a relatively small quantity of water is added to an absolutely dry soil or other powdered solid, there is some shrinkage in the apparent volume of the soil or powder. The water spreads over the surfaces of the solid particles in a film, and a rise in temperature shows that a noticeable energy change accompanies the formation of the film. ${ }^{1}$ With further increments of water the apparent volume of the soil increases until a maximum is reached. The water content at which this maximum volume of soil can be attained is a definite physical characteristic for any given soil. What is popularly known as the "optimum water content" corresponds to this critical content. ${ }^{2}$ It is the point at which further additions of water will not increase the thickness of the moisture film on the soil grains, but will give free water in the

${ }^{1}$ See, in this connection, Energy changes accompanying absorption, by Harrison E. Patten, Trans. Am. Electrochem. Soc., II, 387-407 (I907); see also the recent valuable research, Les dégagements de chaleur qui se produisent au contact de la terre sèche et de l'eau, par A. Muntz et $\mathrm{H}$. Gaudechon, Ann. sci. agron. (3), 4, II, 393-443, I909, where it is shown that probably a part of the heat is due to chemical combination between the water and the other soil components. To quote, "Ces diverses observations nous conduisent à penser, sans nous en donner toutefois la preuve absolue, que la fixation de l'eat sur les éléments terreux très fins et sur les matériaux organisés, est tout au moins, en partie, attribuable à une combinaison chimique qui se manifeste non seulement par un fort dégagement de chaleur, mais aussi par la soustraction de l'eau à des substances aux-quelles elle semble chimiquement liée."

2 The moisture content and physical condition of soils, by Frank $\mathrm{K}$. Cameron and Francis E. Gallagher, Bull. No. 50, Bureau of Soils, U. S. Dept. Agriculture, I908. 
soil interstices. Just as the apparent volume of a given mass of soil varies with the water content, and reaches a maximum at a critical moisture content, so do all the physical properties vary and have either a maximum or minimum value at this same critical moisture content. Thus the apparent specific gravity of a soil reaches a minimum, the force required to insert a penetrating tool becomes a minimum, while the rate at which a soil warms up reaches a maximum, ${ }^{1}$ and the ease with which aeration takes place reaches a maximum. In fine, this critical water content is that at which the soil can be brought into the best possible physical condition for the growth of crops. The practical significance of the optimum water content is far greater than would be supposed from the attention given it hitherto by students of the soil. It is the content of soil water which the greenhouse man should strive to maintain, and which the irrigation farmer should seek to provide, instead of the overwetting so common to the practice of both. In general farming it is that moisture content at which the farmer will attain the best results in plowing and cultivating, and attain these results most readily.

With additions of water beyond the critical point, there is a presence of free water in the soil interstices accompanied by important changes in the soil structure. With continued additions, there is a more or less rapid decrease in the apparent volume; there is a tendency for the soil aggregates to break down and the "crumb structure" so greatly desired by agriculturists is less and less readily obtained, and working of the soil tends in some cases to produce that phenomenon known as "puddling." However desirable the property of puddling may be to the potter or the brick maker, to the farmer it is a bane to be avoided above all things. To overcome it requires his best skill, and it usually takes several years of patient effort to restore a puddled soil to good tilth.

The force with which the film water is held against the

${ }^{1}$ Heat transference in soils, by Harrison E. Patten, Bull. No. 59, Bureau of Soils, U. S. Dept. Agriculture, Igog. 
soil-grains has not been determined as yet with any degree of precision, but it is certainly very great. If a soil be saturated, that is, if so much water be added that further additions will cause a flow of free water, and the soil be then submitted to some mechanical device for abstracting the water, the moisture content of the soil can be readily diminished to the critical water content; but to diminish it further by mechanical means is not easy. The tenacity with which film water is held by the soil grains has been shown in several ways. In one of these, for instance, a semi-permeable membrane was precipitated in the walls of a porous clay cell, which was then filled with sugar solution having an osmotic pressure of about 35 atmospheres. When this cell was buried in a soil having a moisture content above the optimum, water flowed into the cell. On the contrary, when the cell was buried in another sample of the same soil having a moisture content well below the optimum, there was a marked flow of water from the cell. It would appear, therefore, that the attraction between the soil grains and the filmforming water was certainly greater than the solution pressure of the sugar. ${ }^{1}$ Again, by whirling wetted soils in a rapidly revolving centrifuge, ${ }^{2}$ fitted with a filtering device in the periphery, and developing a force equivalent on the average to 3,000 times the attraction of gravitation, the soils could not be reduced below the critical water content. From the results of Lagergren, ${ }^{3}$ Young, ${ }^{4}$ and Lord Rayleigh, ${ }^{5}$ it appears that the force holding a very thin moisture film on the soil grains would be of an order of magnitude from 6,000 to 25,-

1 The chemistry of the soil as related to crop production, by Milton Whitney and Frank K. Cameron, Bull. No. 22, Bureau of Soils, U. S. Dept. Agriculture, I903, p. 54 .

2 The moisture equivalent of soils, by L,yman J. Briggs and John W. McLane, Bull. No. 45, Bureau of Soils, U. S. Dept. Agriculture, 1907.

${ }^{3}$ Uber die beim Benetzen fein verteilter Körper auftretende Wärmetönung, von Lagergren, Bihang till K. sv. Vet.-Akad., Handil., 24, Afd. II, No. 5 (1898).

${ }^{4}$ Minchin: Hydrostatics and elementary hydrokinetics, 3 II, I892.

${ }^{5}$ On the theory of surface forces, by Lord Rayleigh, Phil. Mag. (5), 30, $285^{-298}, 45^{6-475}$ (I890). 
ooo atmospheres. This force, however, must greatly decrease with thickening of the film, as is shown by the fact that at the critical moisture content a small further addition of water produces no marked heat manifestation, though making a noticeable difference in the physical properties of the soil. Therefore, while recognizing that our knowledge of this force still lacks a desirable precision, it is nevertheless clear that the force is very great.

The function of the film water in maintaining the soil structure is undoubtedly important. A soil in good tilth, or good condition for crop growth, shows a peculiar structural arrangement of the individual soil grains or soil particles, which it is very difficult to describe in precise terms, but which is readily recognized in practice. This condition is usually described as a "crumb structure," either because of its appearance or because of the peculiar crumbly feeling which a soil in this condition gives when rubbed between the fingers. The individual grains of soil are gathered into groups or floccules. While other causes may be more or less operative in particular cases, it seems very probable that the film water is primarily the agency holding together the grains in these floccules. The obvious explanation is that the film is exerting a holding power because of its surface tension. It follows, therefore, that anything which affects the surface tension of water should affect the structure of the soil; that is, the flocculation or granulation of the particles. But certain agents which produce respectively flocculation or deflocculation, nevertheless modify the surface tension of the solution in the same direction, and in not widely varying degree. Similar difficulties arise in attempting to correlate "crumbing" phenomena with the viscosity of the film water, ${ }^{1}$ and it must be admitted frankly that present views on this subject are very unsatis-

${ }^{2}$ Equally unsuccessful is the attempt to correlate flocculating agents with changes in the density of water; see, The condensation of water by electrolytes, by F. K. Cameron and W. O. Robinson, Jour. Phys. Chem., I4, I-II (1900). 
factory, and that more careful investigation is urgently needed on this fundamental and important problem. Not only is the absence of a satisfactory theory embarrassing in considering the problems of soil structure and a rational control, but the difficulties are no less in the equally important problems of the movement of film moisture, and the distribution of moisture in a soil.

The movement of moisture into a soil from an illimitable supply is a comparatively simple phenomenon, controlled by a rate law which may be expressed by the equation $y^{n}=k t$ when $y$ is the distance through which the movement has taken place; $t$ is the time, and $k$ and $n$ are characteristic constants for the particular soil and solution. ${ }^{1}$ This formula also describes the rate of advance of a dissolved substance into the soil.

It has also been shown repeatedly by experiment that the movement of moisture is relatively rapid when the moisture content of the soil is above the optimum, but that the movement is exceedingly slow when the soil has a lower water content than the optimum; that is, the point at which the water is entirely in the form of film water. For instance, if a moderately wet sample of soil be brought into intimate contact with an air-dry sample of the same soil, there will, at first, be a relatively rapid movement of the moisture, but as soon as the wetted portion has been brought to the "optimum" condition, no further movement can be detected, although the experiment has been tried of leaving such samples together for months and with a difference of water content amounting, in the case of clay soils, to 15 or 20 per cent. Since the drought limit, or the soil moisture content at which plants wilt, is, for most soils, considerably below the optimum water content, the movement of film water is obviously a problem of the first importance from a practical point of view as well as of the highest theoretical interest.

${ }^{1}$ See Bull. No. 30, Bureau of Soils, U. S. Dept. Agriculture, p. 50 et seq; also, The flow of liquids through capillary spaces, by J. M. Bell and F. K. Cameron, Jour. Phys. Chem., ro, 659 (1906). 
The movement of water vapor, or its distillation from place to place in the soil, is another problem often confused with the above. Its importance is not yet clear, although according to some investigators ${ }^{1}$ it would appear that the addition of soluble fertilizer salts by causing a lowering of the vapor pressure of the water induces a distillation to that region from other regions of the soil as well as from the atmosphere above. This brings up the problem of the diffusion of water and other vapors through the soil. It has been shown that the soil "plug" retards the rate at which diffusion takes place but induces no other effect in the ordinary phenomenon of free diffusion. This fact is obviously of the first importance in the theory of mulches, but requires no further consideration here. ${ }^{2}$

\section{The Mineral Constituents of the Soil Solution ${ }^{3}$}

The mineral constituents of the soil are products of the disintegration, degradation and decomposition of rocks. The decomposition products are mainly silica in the form of quartz, ferruginous material consisting of more or less hydrated ferric oxide and alumina, and hydrated aluminum silicate. The ferruginous material, being deposited or formed in the soil in a very finely divided condition, frequently coats the soil fragments to such an extent as completely to mask their true character. But if a soil be thoroughly shaken with water, and especially in the presence of some deflocculating agent such as a slight excess of ammonia, as in the ordinary preparation of a soil sample for mechanical analysis, ${ }^{4}$ the coating

' Sur la diffusion des engrais salins dans le terre, par Muntz et Gaudechon, Comptes rendus, I48, 253-258 (rgog).

${ }^{2}$ See, Contribution to our knowledge of the aeration of soils, and Studies on the movement of soil moisture, by Edgar Buckingham, Bulls. Nos. 25 and 38, Bureau of Soils, U. S. Dept. of Agriculture.

${ }^{8}$ For a more detailed discussion and citations of the literature, see The mineral constituents of the soil solution, by Frank K. Cameron and James M. Bell, Bull. No. 30, Bureau of Soils, U. S. Dept. Agriculture, I905.

${ }^{4}$ Centrifugal methods of mechanical soil analysis, by L. J. Briggs, F. O. Martin and J. R. Pearce, Bull. No. 24, Bureau of Soils, U. S. Dept. Agriculture, I904. 
material is generally removed quite readily, and the mineral particles appear as fragments and splinters of the ordinary rock-forming minerals. Sometimes these fragments are more or less worn and rounded at the edges, showing mechanical abrasion or solvent action; sometimes they show evidences of partial alteration and decomposition; but surfaces of the unaltered mineral individuals always are found. These unaltered minerals occur as fragments of all sizes, and are to be found in the sands, silts, and presumably in the clays. As might be anticipated, the minerals other than quartz generally show a tendency to segregate in the finer mechanical separations of the soil. The presence of these unaltered mineral fragments in the clays has so far defied direct experimental proof because of the limitations of the microscope, but from chemical reasoning and a priori considerations there can be but little doubt that they exist in the clays as in the coarser separations. ${ }^{1}$

An important result of researches on the minerals of the soil is the generalization that soils are far more heterogeneous than are rocks, and that practically every soil contains all the common rock-forming minerals. ${ }^{2}$ This generalization is 'subject to some qualifications. It would hardly be fair to regard a beach sand, for instance, as a normal soil. Yet it is surprising how many minerals other than quartz can usually be found even in a beach sand. Opinions may differ as to just what are the common rock-forming minerals, and perhaps no two mineralogists or petrographers would give identical lists, but there are a number of minerals which would appear undoubtedly in every list, and these would be found generally in any soil. Again, it might happen that in any given sample of soil, no pyroxene, for instance, could be found; but ex-

${ }^{2}$ See, The mineral composition of soil particles, by G. H. Failyer, J. G. Smith and H. R. Wade, Bull. No. 54, Bureau of Soils, U. S. Dept. Agriculture, 1909. Recent improvements in microscope methods make it possible to identify without serious trouble the mineral content of silts with a diameter as low as $0.005 \mathrm{~mm}$, and many even of the clay particles have recently been determined with satisfactory accuracy.

${ }^{2}$ See Bull. No. 30, Bureau of Soils, U. S. Dept. Agriculture, p. 9. 
perience shows that it would never happen in such a case that no amphibole, chlorite, serpentine, or other ferro-magnesian silicates would be present. However distinct these minerals cited may be from each other morphologically or optically, they are much the same in their chemical characteristics, their solubilities and their reactions with water and such dilute solutions as exist in the soil. Hence from the point of view of the soil chemist they may be considered for all practical purposes varieties of one and the same mineral species.

It is not difficult to account for the heterogeneity of the mineral content of the soil. Many of our rocks are reconsolidated soils, and the alternating formation of rock and soil from the same materials is probably an agency, in some part at least, in the mixing of soil material. The action of water in carrying off and transporting surface material and in gullying and eroding sloping surfaces is probably a large factor. But this agency, like the first, is rather restricted and localized. Just as important as a mixing agency is the wind. This, unlike water, works uphill as well as down, and is more or less in action at all times, continually transporting soil material from place to place. Wind-borne dust on roofs of dwellings, on rocky mountain tops and similar places, where it could have been brought by no other agency than the wind, is sometimes found supporting vegetation. Many chemical and mineralogical analyses of wind-borne dust obtained from various locations show it to have generally the same essential characteristics as ordinary soils.

Aside from the quartz and ferruginous materials mentioned above, the major part of the soil minerals are silicates, ferro-silicates, alumino-silicates or ferro-alumino-silicates, of the common bases, sodium, potassium, calcium, magnesium, and ferrous iron. Other bases, such as lithium, barium, or the heavy metals may occasionally be present in appreciable amounts as may other types of silicates, or other mineral salts, but these may be regarded as more or less incidental and rarely affecting in any essential way the general char- 
acter of the soil mass. These silicates or silico minerals are all somewhat soluble in water, and being salts of weak acids with strong bases, are greatly hydrolyzed. A convenient illustration is afforded by the well-known rock and soil mineral, orthoclase. Assuming its type formula, the reaction with water may be represented,

$$
\text { K. } \mathrm{AlSi}_{3} \mathrm{O}_{8}+\mathrm{HOH} \rightleftarrows \mathrm{H} \cdot \mathrm{AlSi}_{3} \mathrm{O}_{8}+\mathrm{KOH} .
$$

Under ordinary soil conditions, with a relatively large proportion of carbon dioxide in the soil atmosphere, the potash formed would be more or less completely transformed to the bicarbonate,

$$
\mathrm{KOH}+\mathrm{CO}_{2}+\mathrm{H}_{2} \mathrm{O} \rightleftarrows \mathrm{KHCO}_{3}+\mathrm{H}_{2} \mathrm{O} \text {. }
$$

Confirmation of this view is afforded by the natural associations and known alteration products of orthoclase.

The acid of the formula $\mathrm{H} \cdot \mathrm{AlSi}_{3} \mathrm{O}_{8}$ is not known and is probably entirely instable under ordinary conditions, and breaks down with the separation of silica, to form the minerals pyrophyllite, kaolinite or kaolin, and diaspore according to the following equations:

$$
\begin{aligned}
& \text { H.AlSi } \mathrm{O}_{8}-\mathrm{SiO}_{2}=\mathrm{H} . \mathrm{AlSi}_{2} \mathrm{O}_{6} \text { (Pyrophyllite) } \\
& \text { H.AlSi } \mathrm{O}_{8}-{ }_{2} \mathrm{SiO}_{2}=\mathrm{H} . \mathrm{AlSiO}_{4} \text { (Kaolinite) } \\
& \text { H.A } \mathrm{AlSi}_{8} \mathrm{O}_{8}-{ }_{3} \mathrm{SiO}_{2}=\mathrm{H} . \mathrm{AlO}_{2} \text { (Diaspore). }
\end{aligned}
$$

All three of these minerals and their corresponding salts have been found in nature as alteration products of orthoclase. It is probable that, under soil conditions, the principal metamorphic product of feldspar is kaolin (or kaolinite when it is crystalline), hydrated aluminum oxide being of much less importance ${ }^{1}$ and pyrophyllite of doubtful occurrence. A still more interesting case, perhaps, because of the well recognized tendency of magnesium salts to form basic compounds, is the alteration of pyroxene, amphibole and olivine

${ }^{1}$ See Ueber die Bildung von Bauxit und verwandte Mineralien, von $\mathrm{A}$. Liebrich, Zeit. prakt. Geol., 1897, 212 214. 
with the formation of a chlorite or serpentine, common associations in nature, which may be represented

$$
\mathrm{MgSiO}_{3}+\mathrm{HOH} \rightleftarrows \mathrm{MgSiO}_{3} \cdot n \mathrm{Mg}(\mathrm{OH})_{2}+\mathrm{SiO}_{2} .
$$

It is tacitly assumed in the foregoing statements that the reaction between a silicate mineral and water is a reversible reaction. This is not definitely known to be the case, for the formation of the ordinary silicate rock-forming minerals in the wet way at ordinary temperatures has as yet been realized in only a few cases. The assumption has, however, some experimental support. Minerals have been often made in the wet way at somewhat elevated temperatures, especially interesting cases in this connection being the formation of orthoclase by Friedel and Sarasin ${ }^{1}$ at slightly elevated temperatures, and the formation of zeolites by Gonnard. ${ }^{2}$ Feldspars and zeolites are common natural associations, it being generally conceded that zeolites are alteration products of the feldspars through the action of water; but Van Hise ${ }^{3}$ has pointed out that under conditions of weathering such as would obtain in the soil, the tendency is for the zeolites to alter to feldspars. Wöhler's classical experiment of recrystallizing apophyllite from hot water ${ }^{4}$ is significant, for only the products of hydrolysis should be obtained if there is an irreversible reaction between the mineral and water. Lemberg found that leucite $\left(\mathrm{KAISi}_{2} \mathrm{O}_{8}\right)$ when treated with an aqueous solution containing ro percent or more of sodium chloride, was partially transformed to analcite $\left(\mathrm{NaAlSi}_{2} \mathrm{O}_{8} \cdot n \mathrm{H}_{2} \mathrm{O}\right)$, potassium chloride being formed at the same time. The reverse reaction was also realized, that is, the partial conversion of analcite to leucite by treatment with a solution of potassium

${ }^{1}$ Sur la reproduction par voie aqueuse du feldspath orthose, par Friedel et Sarasin, Comptes rendus, 92, 1374 (1881).

2 Note sur une observation de Fournet, concernant la production des zéolites a froid, par F. Gonnard, Bull. Soc. min. France, 5, 267-269 (1882); Jahrb. Min., I884, I, Ref. 28.

${ }^{3}$ U. S. Geol. Surv. Monograph, 47 , A treatise on metamorphism, by Charles R. Van Hise, 1904, p. 333.

${ }^{4}$ Jahresb. Fortschr. Chemie Liebig and Kopp, 1847-48, 1262; note. 
chloride, and similar transformations were carried out with the feldspars. ${ }^{1}$ Lemberg's experiments are of especial value as they were carried out at ordinary as well as at high temperatures. It appears probable, therefore, that the hydrolysis of a silicate of the alkalis or alkaline earths is a reversible reaction. It should be noted, however, that Kahlenberg and Lincoln ${ }^{2}$ have shown that probably, in very dilute solutions of alkali silicates, the hydrolysis is practically complete and the silica is nearly all present as colloidal silica and not as silicic acid. Nevertheless, at higher concentrations silicates are formed, and there is abundant evidence in nature that the alumino- or ferro-silicates are reacting with bases to form salts, for example such as the micas. ${ }^{8}$ If the hydrolysis were quite complete, it would appear to follow that the reaction between water and the silicate is irreversible. In that case it is difficult to see how any silicate mineral could persist in the soil for any length of time, and all soils should soon become sterile wastes composed essentially of quartz, kaolin and ferruginous oxides. It has been suggested that the original mineral particles are protected from decomposition by the formation of a coating "gel.", If diffusion can take place through the gel, solution and hydrolysis' of the mineral would proceed, although the presence of the gel would probably retard the rate of the reaction. If it be postulated, however, that diffusion through the gel does not take place, the minerals of the soil can have no influence on the composition of the soil solution, which is an unthinkable alternative. The presence of such gels in the soil has frequently been assumed, but satisfactory proof is generally wanting.

${ }^{1}$ Ueber Silicatumwandlungen, von J. Lemberg, Zeit. deutsch. geol. Ges., 28, 519-62I (1876); Inaug. diss. Dorpat, I877; Bied. Centbl., 8, 567-577 (I879).

${ }^{2}$ Solutions of silicates of the alkalis, by L. Kahlenberg and A. T. Lincoln, Jour. Phys. Chem., 2, 77-90 (1898).

${ }^{8}$ Van Hise, loc. cit., p. 693.

4 For an experimental demonstration of the formation of such a gel, see, The effect of water on rock powders, by Allerton S. Cushman, Bull. No. 92, Bureau of Chemistry, U. S. Dept. Agriculture, I905. 
In general, the same kind of considerations developed for orthoclase hold for the other soil minerals. If minerals of this character be pulverized or ground reasonably fine and then be shaken with distilled water which has been previously boiled to eliminate the dissolved carbon dioxide, the resulting solution will give an alkaline reaction with such indicators as phenolphthalein or litmus. ${ }^{1}$ If a soil be shaken up thoroughly with water, the resulting solution filtered free of suspended matter, as by passing through a Pasteur-Chamberland bougie, and then boiled to eliminate the carbon dioxide, in the vast majority of cases the solution will also give an alkaline reaction with phenolphthalein or litmus. The waters of most of our springs, ponds, creeks or rivers being natural soil solutions, give an alkaline reaction after boiling.

But the mineral content of these natural waters varies greatly. These waters are composed in part of the "runoff," in part of a portion of the "cut-off" waters, described above. This portion of the cut-off, normally, in passing through the soil goes mainly through the larger interstices. It is not long in contact with the individual soil particles and floccules, and because diffusion of dissolved mineral substances is quite slow, especially in dilute solutions, it takes up but little mineral matter from such aqueous films as it may intercept.

A different state of things exists with that portion of the cut-off water which returns towards the surface by reason of capillary forces, to form the great natural nutrient medium for plants. This water is moving over the soil particles in films, and with slowness. It is long in contact with successive fragments of any particular-mineral and all the different minerals making up the soil. Consequently, it tends towards a saturated solution with respect to the mineral mass; and it follows that if every soil contains all the common rock-form-

${ }^{1}$ In making such experiments in the laboratory or in lecture demonstrations, it is well to have the mass of water large in comparison with the mass of powdered mineral or rock; otherwise secondary absorption effects may occur and obscure the results of the hydrolysis. 
ing minerals, every soil should give the same saturated solution, barring the presence of disturbing factors. ${ }^{1}$ Disturbing factors, however, enter into all cases under field conditions, such for instance as the presence of some uncommon or unusual mineral in appreciable amounts, differences in temperature, surface effects, or extraneous substances. These will be considered later, but another disturbing factor requires immediate consideration.

In every soil, varying proportions of the soluble mineral constituents are present otherwise than as definite mineral species; that is, they are present as solid solutions, or adsorbed on the soil grains or perhaps absorbed in some other manner. The concentration of the liquid solution in contact with a solid solution or complex of absorbent and absorbed material is dependent upon the concentration in the solid phase, and consequently upon the relative miasses of solution and solid. Thus, the concentration of a solution with respect to phosphoric acid, when brought into contact with so-called basic phosphates of lime or iron, is dependent in a marked way upon the proportion of solution to solid. ${ }^{2}$ Consequently it is to be expected that an aqueous extract of a soil will vary in concentration with the proportion of water used; and that with the same proportion of water, different soils or different samples of the same soil will yield different concentrations.

How far absorbed mineral constituents affect the solubility of the definite minerals in the soil or influence the concentration of the soil solution, it is not possible to predict with any approach to certainty. Those soils which hold the

${ }^{1}$ Feldspars certainly, and phosphorites possibly, are mineral components of the soil; and these substances when ground sufficiently fine have been added to soils with sometimes an increased production of crop. Other minerals, such as letcite, have given similar results. But also apparently pure quartz sand sometimes accomplishes the same results, as for example, in the experiments of Hilgard cited above. It has not been shown, however, that the addition of any of these substances produces an appreciable change in the concentration of the soil solution.

2 The action of water and aqueous solutions upon soil phosphates, by Frank K. Cameron and James M. Bell, Bull. No. 4I, Bureau of Soils, U. S. Dept. of Agrictilture, 1907. 
most moisture are generally the best absorbers. Moreover, the soluble mineral constituents of the soil, for instance potassium or phosphoric acid, are absorbed to a very high degree from dilute solutions. Consequently it is to be expected that variations in the concentration of the natural soil solution would be less than in aqueous extracts, when there is employed a constant and large proportion of water to soil.

Many attempts have been made to extract the solution naturally existing in the soil and to analyze it. The results obtained have not been very satisfactory, owing mainly to the mechanical difficulties involved. As pointed out above, the solution in a soil under suitable conditions for crop growth is held by a force of great magnitude. Nevertheless, by using powerful centrifuges, with saturated soil, it has been possible to throw out the excess of solution over the critical water content of the soil. In this way small quantities, generally a very few cubic centimeters at a time, have been obtained. The analysis of a few cubic centimeters of a very dilute solution is in itself difficult, involving necessarily more or less uncertainty as to the absolute value of the results. Nevertheless, the concentration of the soil solutions thus obtained, with respect to phosphoric acid and potash, varied but little for soils of various textures from sands to clays, and the variations observed could not be correlated with the known cropproducing power of the soils. The average concentrations of the soil solutions thus obtained lies in the neighborhood of 6-8 parts per million (p.p.m.) of solution for phosphoric acid $\left(\mathrm{P}_{2} \mathrm{O}_{5}\right)$ and 25-30 parts per million for potash $\left(\mathrm{K}_{2} \mathrm{O}\right) .{ }^{1}$ In the following table are given the results obtained by analyzing solutions extracted from different samples of loams and sands by means of a centrifuge. The crop growing on these soils and the crop condition at the time the samples were collected

1 In this connection it is interesting to note that recent investigations on the proportions of phosphoric acid, potassium and nitrates in cultural solutions best adapted to the growth of wheat, give the same ratio of phosphoric acid to potassium as the figures just cited show to exist normally in the soil solution. 
are given in the table, and the percentages of water in the samples when placed in the centrifuge are also given.

Analysis of SoIl Solution Removed from Fresh SoIls by the CENTRIFUge

\begin{tabular}{|c|c|c|c|c|c|c|}
\hline \multirow{2}{*}{ Soil } & \multirow{2}{*}{ Crop } & \multirow{2}{*}{$\begin{array}{l}\text { Condition } \\
\text { of crop }\end{array}$} & \multirow{2}{*}{$\begin{array}{l}\text { Percent } \\
\text { mois- } \\
\text { ture }\end{array}$} & \multicolumn{3}{|c|}{$\begin{array}{l}\text { Parts per million } \\
\text { of solution }\end{array}$} \\
\hline & & & & $\mathrm{PO}_{4}$ & $\mathrm{Ca}$ & $\mathbf{K}$ \\
\hline Leonardtown loam & Wheat & Good & 22.0 & 6 & I7 & 22 \\
\hline Leonardtown loam & Wheat & Poor & 25.2 & IO & 9 & I9 \\
\hline Leonardtown loam & Wheat & Good & I 7.6 & .8 & 22 & 38 \\
\hline Sassafras loam & Clover & Good & 19.7 & 5 & I 8 & I9 \\
\hline Sassafras loam & Corn & Medium & $I 7 \cdot 5$ & 8 & I3 & 36 \\
\hline Sassafras loam & Corn & Medium & 18.3 & 8 & 83 & 25 \\
\hline Sassafras loam & Wheat & Good & I 8.8 & 7 & 44 & 34 \\
\hline Sassafras loam & Wheat & Poor & 20.0 & 7 & 27 & 24 \\
\hline Sassafras loam & Corn & Good & $17 \cdot 3$ & 8 & 24 & 25 \\
\hline Norfolk sand & Forest & Poor & 10. 0 & 5 & 18 & $3^{I}$ \\
\hline Norfolk sand & Corn & Good & I I. 9 & I I & 36 & $3 \mathbf{I}$ \\
\hline Norfolk sand & Wheat & Good & 10.7 & 18 & 45 & $3 I$ \\
\hline Norfolk sand & Wheat & Poor & I I . 2 & 8 & 38 & 24 \\
\hline Norfolk sand & Corn & Medium & I0.6 & $\cdot 9$ & 65 & 35 \\
\hline
\end{tabular}

The concentrations of the solutions obtained from the samples do not justify any correlation with the crop-producing power of the soils, nor with the texture of the soils. The wide variation in the concentrations with respect to calcium is probably due to the fact that all of the samples came from fields which had been limed, some quite recently, and that the content of carbon dioxide in the different samples varied. It is of special interest to note that the content of calcium in the solutions does not show any obvious relation to the content of phosphoric acid. ${ }^{1}$

An effort has been made to ascertain the mineral concentration of soil solutions as they occur naturally in the field.

${ }^{1}$ For the literature of the earlier work on the composition of aqueous extracts of soils, see: How crops feed, by Samuel W. Johnson, I890, p. 309 et seq; see also, On the analytical determination of probably available "mineral" plant food in soils, by Bernard Dyer, Jour. Chem. Soc., 65, II5-I67 (I894); and Soils, by E. W. Hilgard, 1906, p. 327 et seq. 
Because of the practical impossibility of extracting the actual soil solution, an empirical method was employed. Areas were selected where good and poor crops were growing near each other on the same soil types, and preferably in the same field. Samples of soil from under these crops were taken at several intervals during the growing season, quickly removed to a nearby laboratory, shaken thoroughly with distilled water in the proportion of one part of soil to five parts of water, allowed to stand twenty minutes and the supernatant solution passed through a Pasteur-Chamberland filter. ${ }^{1}$

As has been pointed out above, the aqueous extract of a soil thus arbitrarily prepared has no definite or causal relation to the soil solution in the field. It is certain that the solutions would not generally be the same. It should also be emphasized that such a procedure can not, as some investigators have assumed, afford a criterion between soluble and insoluble salts in the soil, else the proportion of water to soil used above some minimum would be immaterial as far as the amounts which go into solution are concerned. The proportion of water to soil is not immaterial, however, considering the chemical nature of the soil components and the results of experiment. Consequently, it is clear that the concentration of the soil solution is not simply the ratio of the amounts found in the aqueous extract, to the percentage of moisture in the soil, but something quite different.

Artificial solutions prepared in the manner described above should, however, furnish evidence as to whether or not there are recognizable differences in the soluble mineral constituents of good and poor soils respectively; and if such differences exist, whether they are consistent. That is to say, if the more productive soils also uniformly yield aqueous extracts of a higher concentration, then it would be a fair

${ }^{1}$ Capillary studies and filtration of clays from soil solutions, by Lyman J. Briggs and Macy H. Lapham, Bull. No. 19, Bureau of Soils, U. S. Dept. Agriculture, 1902; Colorimetric, turbidity and titration methods used in soil investigations, by Oswald Schreiner and George H. Failyer, Bull. No. 3I, Bureau of Soils, U. S. Dept. Agriculture, r9o6. 
inference that their natural soil solutions are maintained at a higher concentration than in the less productive soils.

Results obtained for several localities and several crops, taken from the original records, are given in the following tables. ${ }^{1}$

Water Soluble Constituents of SoIL

Locality, Salem, N. J. Soil type, Norfolk sand. Crop, wheat. Yield, good

\begin{tabular}{|c|c|c|c|c|c|}
\hline \multirow{2}{*}{$\mathrm{Da}$} & \multirow{2}{*}{$\begin{array}{l}\text { Depth } \\
\text { Inches }\end{array}$} & \multirow{2}{*}{$\begin{array}{l}\text { Moisture } \\
\text { content } \\
\text { Percent }\end{array}$} & \multicolumn{3}{|c|}{$\begin{array}{l}\text { Parts per million of oven-dried } \\
\text { soil }\end{array}$} \\
\hline & & & $\begin{array}{l}\text { Phosphoric } \\
\text { acid }\left(\mathrm{PO}_{4}\right)\end{array}$ & $\begin{array}{l}\text { Calcium } \\
(\mathrm{Ca})\end{array}$ & $\begin{array}{l}\text { Potas- } \\
\text { sium }(K)\end{array}$ \\
\hline March I & $\begin{array}{r}0-12 \\
12-24\end{array}$ & $\begin{array}{l}\text { I } 3.2 \\
\text { I I. } 5\end{array}$ & $\begin{array}{r}12 \\
7\end{array}$ & 5 & $\begin{array}{l}12 \\
16\end{array}$ \\
\hline June & $I-24$ & $4 \cdot 3$ & 4 & I4 & 13 \\
\hline June I & I-24 & 4.6 & 5 & I 3 & 17 \\
\hline June & $I-24$ & 9.6 & 2 & 14 & 24 \\
\hline
\end{tabular}

Locality, Salem, N. J. Soil type, Norfolk sand. Crop, wheat. Yield, poor

\begin{tabular}{|c|c|c|c|c|c|}
\hline \multirow{2}{*}{ Date } & \multirow{2}{*}{$\begin{array}{l}\text { Depth } \\
\text { Inches }\end{array}$} & \multirow{2}{*}{$\begin{array}{c}\text { Moisture } \\
\text { content } \\
\text { Percent }\end{array}$} & \multicolumn{3}{|c|}{$\begin{array}{c}\text { Parts per million of oven-dried } \\
\text { soil }\end{array}$} \\
\hline & & & $\begin{array}{l}\text { Phosphoric } \\
\text { acid }\left(\mathrm{PO}_{4}\right)\end{array}$ & $\begin{array}{l}\text { Calcium } \\
\text { (Ca) }\end{array}$ & $\begin{array}{l}\text { Potas- } \\
\operatorname{sium}(\mathrm{K})\end{array}$ \\
\hline \multirow[t]{2}{*}{ April 3} & $\mathrm{O}-\mathrm{I} 2$ & I2.O & I I & 5 & 32 \\
\hline & I $2-24$ & 12.0 & IO & 3 & 22 \\
\hline June 16 & $\mathrm{I}-24$ & $9 \cdot 3$ & 4 & 29 & 20 \\
\hline
\end{tabular}

${ }^{1}$ The chemistry of the soil as related to crop production, by Milton Whitney and F. K. Cameron, Bull. No. 22, Bureau of Soils, U. S. Dept. Agriculture, 1903 . 
Locality, Salem, N. J. Soil type, Sassafras loam. Crop, wheat. Yield, medium

\begin{tabular}{|c|c|c|c|c|c|}
\hline \multirow{2}{*}{ Date } & \multirow{2}{*}{$\begin{array}{l}\text { Depth } \\
\text { Inches }\end{array}$} & \multirow{2}{*}{$\begin{array}{c}\text { Moisture } \\
\text { content } \\
\text { Percent }\end{array}$} & \multicolumn{3}{|c|}{$\begin{array}{l}\text { Parts per million of oven-dried } \\
\text { soil }\end{array}$} \\
\hline & & & $\begin{array}{l}\text { Phosphoric } \\
\text { acid }\left(\mathrm{PO}_{4}\right)\end{array}$ & $\underset{(\mathrm{Ca})}{\text { Calcium }}$ & 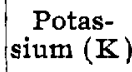 \\
\hline \multirow[t]{2}{*}{ March ro } & $0-12$ & 23.2 & I9 & IO & 8 \\
\hline & I $2-24$ & 21.6 & I I & Io & I 4 \\
\hline \multirow[t]{3}{*}{ March I4 } & $0-12$ & $22 \cdot 3$ & r 8 & 8 & I 8 \\
\hline & $12-24$ & 20.2 & $x_{5}$ & I 2 & $2 \mathrm{I}$ \\
\hline & $24-36$ & 20.3 & I8 & I7 & I6 \\
\hline \multirow[t]{3}{*}{ March 20} & $0-12$ & $19 \cdot 3$ & 7 & IO & 2 I \\
\hline & I $2-24$ & 18.6 & 4 & I I & $2 \mathrm{I}$ \\
\hline & $24-36$ & 12.6 & 5 & 12 & 21 \\
\hline June $\quad 16$ & I- 24 & 22.5 & 4 & 24 & 23 \\
\hline
\end{tabular}

Locality, Salem, N. J. Soil type, Sassafras, loam. Crop, grass. Yield, fair

\begin{tabular}{|c|c|c|c|c|c|}
\hline \multirow{2}{*}{ Date } & \multirow{2}{*}{$\begin{array}{l}\text { Depth } \\
\text { Inches }\end{array}$} & \multirow{2}{*}{$\begin{array}{c}\text { Moisture } \\
\text { content } \\
\text { Percent }\end{array}$} & \multicolumn{3}{|c|}{$\begin{array}{l}\text { Parts per million of oven-dried } \\
\text { soil }\end{array}$} \\
\hline & & & $\begin{array}{l}\text { Phosphoric } \\
\text { acid }\left(\mathrm{PO}_{4}\right)\end{array}$ & $\begin{array}{l}\text { Calcium } \\
\text { (Ca) }\end{array}$ & $\begin{array}{l}\text { Potas- } \\
\operatorname{sium}(\mathrm{K})\end{array}$ \\
\hline \multirow[t]{3}{*}{ March Io } & $0-12$ & 25.0 & I3 & 28 & I 8 \\
\hline & I $2-24$ & 23.8 & 7 & 26 & I3 \\
\hline & $24-36$ & 19.9 & I6 & 8 & I5 \\
\hline \multirow[t]{3}{*}{ March I4 } & $0-12$ & 25.8 & $2 \mathrm{I}$ & 12 & $2 I$ \\
\hline & I $2-24$ & $23 . I$ & 8 & I 2 & I 5 \\
\hline & $24-36$ & 21.8 & 9 & I 5 & $2 \mathrm{I}$ \\
\hline \multirow[t]{2}{*}{ March 3I } & $0-12$ & 23.0 & II & 23 & 43 \\
\hline & I $2-24$ & 21.6 & 8 & 20 & 34 \\
\hline \multirow[t]{3}{*}{ April } & $\mathrm{O}-\mathrm{I} 2$ & 24.8 & 8 & 16 & $4 \mathrm{I}$ \\
\hline & I $2-24$ & 24.0 & 6 & $2 \mathrm{I}$ & 38 \\
\hline & $24-36$ & 21.4 & 3 & I I & 25 \\
\hline
\end{tabular}


Locality, Salem, N. J. Soil type, Sassafras loam. Crop, wheat. Yield, good

\begin{tabular}{|c|c|c|c|c|c|c|c|}
\hline \multirow{2}{*}{\multicolumn{3}{|c|}{ Date }} & \multirow{2}{*}{$\begin{array}{l}\text { Depth } \\
\text { Inches }\end{array}$} & \multirow{2}{*}{$\begin{array}{c}\text { Moisture } \\
\text { content } \\
\text { Percent }\end{array}$} & \multicolumn{3}{|c|}{$\begin{array}{l}\text { Parts per million of oven-dried } \\
\text { soil }\end{array}$} \\
\hline & & & & & $\begin{array}{l}\text { Phosphoric } \\
\text { acid }\left(\mathrm{PO}_{4}\right)\end{array}$ & $\begin{array}{l}\text { Calcium } \\
\text { (Ca) }\end{array}$ & $\begin{array}{l}\text { Potas- } \\
\operatorname{sium}(\mathbf{K})\end{array}$ \\
\hline \multirow{2}{*}{\multicolumn{3}{|c|}{ March I 7}} & $0-12$ & 22.0 & 8 & 6 & IO \\
\hline & & & $12-24$ & I8. I & 8 & I 5 & I4 \\
\hline \multirow{2}{*}{\multicolumn{3}{|c|}{ March 17}} & $0-12$ & I 8.3 & IO & I 5 & Lost \\
\hline & & & I2-24 & I 8. I & 9 & 24 & 25 \\
\hline \multirow{2}{*}{\multicolumn{3}{|c|}{ March 24}} & $\mathrm{O}-\mathrm{I} 2$ & $24 \cdot 7$ & I4 & I2 & 30 \\
\hline & & & $12-24$ & $22 \cdot 3$ & 8 & I I & 38 \\
\hline \multirow{3}{*}{\multicolumn{3}{|c|}{ March 26}} & $0-12$ & $23 \cdot 4$ & 4 & I6 & 16 \\
\hline & & & I $2-24$ & $23 \cdot 9$ & I 2 & I6 & 20 \\
\hline & & & $24-36$ & 22.4 & 8 & 3 & $2 \mathrm{I}$ \\
\hline \multirow[t]{2}{*}{ April } & 2 & & $0-12$ & $25 \cdot 6$ & 8 & I6 & 30 \\
\hline & & & $\begin{array}{l}12-24 \\
24-36\end{array}$ & $\begin{array}{l}24.4 \\
2 \text { I. } 6\end{array}$ & $\begin{array}{l}8 \\
8\end{array}$ & $\begin{array}{l}\text { I } 7 \\
\text { II }\end{array}$ & $\begin{array}{l}47 \\
38\end{array}$ \\
\hline \multirow[t]{2}{*}{ June } & 5 & & $0-12$ & $5 \cdot 2$ & I4 & $5^{I}$ & 23 \\
\hline & & & $12-24$ & 8.0 & I 5 & 55 & 32 \\
\hline June & 8 & & $I-24$ & Io. 6 & 2 & 20 & 13 \\
\hline June & I $\mathbf{I}$ & .! & $I-24$ & I $5 \cdot 5$ & 6 & 26 & i. $I_{4}$ \\
\hline June & I3 & & $I-24$ & $\because 8.2$ & 6 & 19 & 22 \\
\hline June & 16 & & $I-24$ & I 5.0 & 5 & $2 \mathrm{I}$ & I9 \\
\hline June & I 7 & & $I-24$ & 10.6 & 7 & 63 & 17 \\
\hline
\end{tabular}

Locality, Salem, N. J. Solid type, Sassafras loam. Crop, clover. Yield, fair

\begin{tabular}{|c|c|c|c|c|c|}
\hline \multirow{2}{*}{ Date } & \multirow{2}{*}{$\begin{array}{l}\text { Depth } \\
\text { Inches }\end{array}$} & \multirow{2}{*}{$\begin{array}{c}\text { Moisture } \\
\text { content } \\
\text { Percent }\end{array}$} & \multicolumn{3}{|c|}{$\begin{array}{c}\text { Parts per million of oven-dried } \\
\text { soil }\end{array}$} \\
\hline & & & $\begin{array}{l}\text { Phosphoric } \\
\text { acid }\left(\mathrm{PO}_{4}\right)\end{array}$ & $\begin{array}{c}\text { Calcium } \\
\text { (Ca) }\end{array}$ & $\begin{array}{c}\text { Potas- } \\
\operatorname{sium}(\mathbf{K})\end{array}$ \\
\hline \multirow[t]{3}{*}{ March 20} & $0-12$ & 20.8 & 5 & I5 & 32 \\
\hline & I 2-24 & 20.2 & 5 & I5 & 27 \\
\hline & $24-36$ & I 8.6 & 5 & I 2 & 36 \\
\hline \multirow[t]{3}{*}{ March 26} & $0-12$ & 26.8 & 9 & $3 \mathrm{I}$ & 20 \\
\hline & I $2-24$ & 22.9 & 8 & 20 & I 8 \\
\hline & $24-36$ & 22.5 & 4 & $\mathrm{r} 4$ & 20 \\
\hline \multirow{2}{*}{ June } & $0-12$ & $8 . \mathrm{I}$ & 8 & 16 & I7 \\
\hline & $12-24$ & 12.7 & 9 & I 8 & 20 \\
\hline
\end{tabular}


Locality, St. Marys, Md. Soil type, Leonardtown loam. Crop, wheat. Yield, good

\begin{tabular}{|c|c|c|c|c|c|c|}
\hline & \multirow{2}{*}{ Date } & \multirow{2}{*}{$\begin{array}{l}\text { Depth } \\
\text { Inches }\end{array}$} & \multirow{2}{*}{$\begin{array}{c}\text { Moisture } \\
\text { content } \\
\text { Percent }\end{array}$} & \multicolumn{3}{|c|}{$\begin{array}{l}\text { Parts per million of over-dried } \\
\text { soil }\end{array}$} \\
\hline & & & & $\begin{array}{l}\text { Phosphoric } \\
\text { acid }\left(\mathrm{PO}_{4}\right)\end{array}$ & $\begin{array}{l}\text { Calcium } \\
(\mathrm{Ca})\end{array}$ & 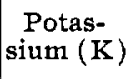 \\
\hline \multirow{2}{*}{\multicolumn{2}{|c|}{ April 27}} & $\mathrm{O}-\mathrm{I} 2$ & 21.8 & 5 & IO & I 2 \\
\hline & & I 2-24 & $21 \cdot 3$ & 4 & 7 & Io \\
\hline \multirow{2}{*}{\multicolumn{2}{|c|}{ April 29}} & $\mathrm{O}-12$ & 22.2 & 8 & I 5 & $5^{2}$ \\
\hline & & I $2-24$ & 21.8 & 4 & I I & $3^{8}$ \\
\hline \multirow[t]{2}{*}{ May } & I & $0-12$ & 22.4 & 7 & I4 & 23 \\
\hline & & I $2-24$ & 21.8 & 7 & 8 & 30 \\
\hline \multirow{2}{*}{ May } & $I$ & $0-12$ & 17.0 & 5 & I6 & 25 \\
\hline & & I $2-24$ & 21.0 & 5 & 7 & I9 \\
\hline \multirow{2}{*}{ May } & 9 & $0-12$ & I 5.0 & I3 & 34 & 28 \\
\hline & & I $2-24$ & I $5 \cdot 9$ & 9 & I 7 & 26 \\
\hline \multirow{2}{*}{\multicolumn{2}{|c|}{ May I5 }} & $0-12$ & 14.2 & 3 & 14 & 24 \\
\hline & & I $2-24$ & $.19 \cdot 9$ & 4 & 13 & 25 \\
\hline \multicolumn{2}{|c|}{ August I4 } & $0-24$ & 15.0 & 6 & I I & 13 \\
\hline \multicolumn{2}{|c|}{ August I 5} & $0-24$ & I $5 \cdot 7$ & 5 & 3 & I 7 \\
\hline \multicolumn{2}{|c|}{ August I 5} & $0-24$ & I 6.4 & 8 & 15 & I 5 \\
\hline
\end{tabular}

Locality, St. Marys, Md. Soil type, Leonardtown loam. Crop, wheat. Yield, poor

\begin{tabular}{|c|c|c|c|c|c|}
\hline \multirow{2}{*}{ Date } & \multirow{2}{*}{$\begin{array}{l}\text { Depth } \\
\text { Inches }\end{array}$} & \multirow{2}{*}{$\begin{array}{c}\text { Moisture } \\
\text { content } \\
\text { Percent }\end{array}$} & \multicolumn{3}{|c|}{$\begin{array}{l}\text { Parts per million of oven-dried } \\
\text { soil }\end{array}$} \\
\hline & & & $\begin{array}{l}\text { Phosphoric } \\
\text { acid }\left(\mathrm{PO}_{4}\right)\end{array}$ & $\begin{array}{l}\text { Calcium } \\
(\mathrm{Ca})\end{array}$ & $\begin{array}{l}\text { Potas- } \\
\operatorname{sium}(\mathrm{K})\end{array}$ \\
\hline \multirow[t]{2}{*}{ May I4 } & $0-12$ & $14 \cdot 7$ & 5 & 8 & 35 \\
\hline & $12-24$ & I9.9 & 4 & 4 & 30 \\
\hline \multirow[t]{2}{*}{ May 23} & $0-12$ & 7.8 & 4 & 7 & 22 \\
\hline & I $2-24$ & 14.9 & 4 & I I & 23 \\
\hline August $\mathrm{I}_{4}$ & $0-24$ & 16.0 & 4 & 4 & 16 \\
\hline August I5 & $0-24$ & 19.5 & 6 & 4 & I3 \\
\hline
\end{tabular}


Locality, St. Marys, Md. Soil type, Leonardtown loam. Crop, corn. Yield, good

\begin{tabular}{|c|c|c|c|c|c|c|}
\hline & \multirow{2}{*}{ Date } & \multirow{2}{*}{$\begin{array}{l}\text { Depth } \\
\text { Inches }\end{array}$} & \multirow{2}{*}{$\begin{array}{c}\text { Moisture } \\
\text { content } \\
\text { Percent }\end{array}$} & \multicolumn{3}{|c|}{$\begin{array}{l}\text { Parts per million of oven-dried } \\
\text { soil }\end{array}$} \\
\hline & & & & $\begin{array}{l}\text { Phosphoric } \\
\text { acid }\left(\mathrm{PO}_{4}\right)\end{array}$ & $\begin{array}{l}\text { Calcium } \\
(\mathrm{Ca})\end{array}$ & $\begin{array}{l}\text { Potas- } \\
\operatorname{sium}(\mathrm{K})\end{array}$ \\
\hline May & 8 & $\begin{array}{r}0-12 \\
12-24\end{array}$ & $\begin{array}{l}\text { I } 8.2 \\
\text { I } 8.0\end{array}$ & $\begin{array}{r}9 \\
10\end{array}$ & I 2 & $\begin{array}{l}29 \\
26\end{array}$ \\
\hline \multicolumn{2}{|c|}{ May I 8} & O-I 2 & I 8.2 & $\begin{array}{l}3 \\
6\end{array}$ & 24 & $\begin{array}{l}38 \\
38\end{array}$ \\
\hline Augu & st 8 & $\begin{array}{l}0-24 \\
0\end{array}$ & 17.5 & 7 & 30 & I 8 \\
\hline
\end{tabular}

Locality, St. Marys, Md. Soil type, Leonardtown loam. Crop, corn. Yield, poor

\begin{tabular}{|c|c|c|c|c|c|}
\hline \multirow{2}{*}{ Date } & \multirow{2}{*}{$\begin{array}{l}\text { Depth } \\
\text { Inches }\end{array}$} & \multirow{2}{*}{$\begin{array}{c}\text { Moisture } \\
\text { content } \\
\text { Percent }\end{array}$} & \multicolumn{3}{|c|}{$\begin{array}{l}\text { Parts per million of oven dried } \\
\text { soil }\end{array}$} \\
\hline & & & $\begin{array}{l}\text { Phosphoric } \\
\text { acid }\left(\mathrm{PO}_{4}\right)\end{array}$ & $\begin{array}{l}\text { Calcium } \\
(\mathrm{Ca})\end{array}$ & $\begin{array}{c}\text { Potas- } \\
\text { sium }(\mathrm{K})\end{array}$ \\
\hline May 23 & $\begin{array}{r}0-12 \\
12-24\end{array}$ & $\begin{array}{l}\text { I6.6 } \\
\text { I } 7.4\end{array}$ & $\begin{array}{l}5 \\
6\end{array}$ & $\begin{array}{r}\mathrm{I} 2 \\
8\end{array}$ & $\begin{array}{l}22 \\
22\end{array}$ \\
\hline $\begin{array}{l}\text { August } 8 \\
\text { August } \cdot 5\end{array}$ & $\begin{array}{l}0-24 \\
0-24\end{array}$ & $\begin{array}{l}19.9 \\
21.6\end{array}$ & $\begin{array}{l}9 \\
7\end{array}$ & $\begin{array}{l}25 \\
\text { I5 }\end{array}$ & $\begin{array}{l}20 \\
13\end{array}$ \\
\hline
\end{tabular}

It will be observed that the results given in the above tables are expressed in parts per million of oven-dried soils, in order to have some definite basis of comparison, and because it was anticipated at the time the investigation was made that larger quantities of dissolved minerals would be found under the better crops, and vice versa. An inspection of the results, however, shows that no such correlation can be made, nor in fact can any consistent correlation be made between the dissolved material and crop, soil type, water content, depth of soil or part of the growing season. ${ }^{1}$ It appears, therefore,

' King, however, claims that the concentration of the soil solution with respect to mineral plant nutrients, is higher in the soils of the northern states than in the soils of the South Atlantic states. See Some results of investigations in soil management, by F. H. King, Yearbook, U. S. Dept. Agriculture, 1903, 
that in so far as the field method of analyzing an arbitrarily prepared aqueous extract is competent, there is no evidence that there are important characteristic differences in the concentration of the mineral constituents in different soil solutions in the field.

The order of concentration of the soil solution can be approximated from the given data, if the assumption be made that in the preparation of the aqueous extract, soluble mineral constituents are of minor importance, other than the constituents already dissolved in the soil solution. The calculation is very laborious, is not exact, and on account of the assumptions made the actual figures obtained are of no especial value in any particular case. Remembering the method of making up the solutions from which these results were obtained, it would be sufficiently near the truth to assume an average moisture content of 20 percent, when the figures given here for the soil approximate those which would be obtained for the soil solution. More exact calculations have been made for a large number of such cases, and it has been found from this method of estimation that the average composition with respect to phosphoric acid would be about 6-8 parts per million, and for potash about 25 parts per million, figures which agree with the results obtained for the examination of solutions extracted from saturated soils by means of the centrifuge.

The results given in the foregoing tables were obtained under great difficulties, and in some part the variations they show are undoubtedly due to inevitable inaccuracies of analytical work done under such circumstances. Some of the variations may also be due to the disturbing influences in the soil referred to above. Experience has shown, however, that the preparation of an aqueous extract of the soil of any particular field is by no means a simple matter. Extracts made from

p. I59-174. Bailey E. Brown has obtained some preliminary results which suggest that there may be seasonal variations with respect to some of the dissolved mineral constituents. See, Annual Report of the Pennsylvania State Experiment Station, 1908-9. 
samples taken within a few feet of one another frequently show variations of the same order as with samples from entirely different fields, or even soil types. Differences in the preliminary drying out of the sample before the addition of the water, seems to result in the same order of differences as obtained between different soils. In consequence of these facts, and of the further fact that an arbitrary aqueous extract of a soil cannot be assumed to represent in any definite way the natural soil solution, the results of the field examination are inconclusive as to the concentration of the soil solution in situ. It is more necessary, therefore, that other lines of evidence should be sought as to the mineral characteristics and concentration of the soil solution. Such a line of evidence is found in certain percolation experiments. ${ }^{1}$

If a solution of a soluble phosphate be percolated through a soil, a part of the phosphate will be removed from the solution and absorbed by the soil; that is, there will be a redistribution of the phosphate between the soil and the water. As. the process continues, however, relatively less and less phosphate is absorbed by the soil and the concentration of the percolate becomes more and more nearly that of the added solution. This absorption takes place more or less closely in accordance with the simple law that the absorption of phosphates by the soil, per unit of solution which is percolating, is proportional to the total amount of phosphate which the soil may yet take from that solution if percolated indefinitely. This law is expressed by the equation $d y / d x=K(A-y)$ where $y$ is the amount absorbed, $x$ amount of solution that has passed, and $A$ is the total amount which can ultimately be absorbed by that particular soil from that particular solution. $K$ is also a characteristic constant. If the percolation be maintained at constant rate, then $t$, time, can be substituted for $x$ and the equation becomes $d y / d t=K(A-y)$, the

1 The absorption of phosphates and potassium by soils, by Oswald Schreiner and George H. Failyer, Bull. No. 32, Bureau of Soils, U. S. Dept. Agriculture, I go6. 
ordinary rate equation for a monomolecular reaction of the first order, whether chemical or physical.

With such absorptions as are involved in soils, a clay exposes a greater amount of absorbing surface than does a loam or sand, and it will show the greatest absorption towards any particular solution, other things being equal. The curve showing the concentration of percolate, would lie lower for a clay than for a loam, or for a sand. This is illustrated in the accompanying sketch diagram, where $y$ represents concentration of percolate and $t$ represents time.

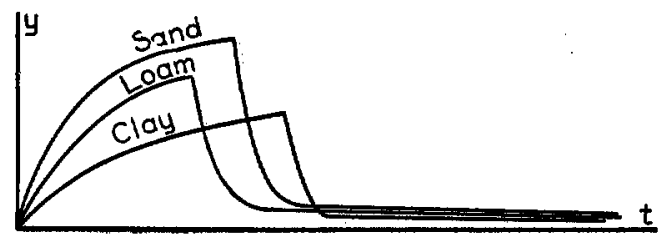

Fig. I.-Absorption and leaching curves.

If after percolation has proceeded for some time (in some experiments for several weeks and until the soil contained I or 2 percent of phosphoric acid) pure water be passed through the soil, then, as soon as the previously used phosphate solution has been displaced, the concentration of the percolate drops, and continues practically constant for an indefinite period. Moreover, no matter what the soil may be as to texture or composition, the same concentration of percolate is obtained, namely, 6-8 parts per million, the concentration which the soils yielded prior to treatment with the phosphate solution. Similar experiments when the soils were treated with salts of potassium have given like results, although the curves obtained from passing pure water through the soils do not lie quite so close together; but the concentration of the percolate with respect to potassium generally lies somewhere between 25 and 30 parts per million.

The removal of a soluble constituent from the soil by percolating water appears to be described by a rate equation 
similar to that given above for absorption. If the rate of percolation be maintained constant this formula is

$$
d x / d t=K(B-x)
$$

where $x$ is the amount removed by the percolation, with time $t, K$ is a constant characteristic for the particular system under consideration, and $B$ is the total amount of the constituent which may ultimately be leached out. In other words, the rate in any particular soil will depend upon the amount of the constituent still absorbed in that soil but has no necessary connection with the rate which would hold for the same amount of the constituent in any other soil.

Theoretically, two consequences follow from this law which require consideration here. The rate at which a constituent is removed gradually becomes less as percolation proceeds. If the soil contains an amount of the constituent approaching the total amount which it can absorb, as for instance is probably the case sometimes when large applications of lime have been made to the soil, the concentration of the percolating solution might be expected to change noticeably. Generally, however, a soil contains nowhere near as much phosphoric acid or potassium as it is capable of absorbing, so that the concentration of the percolating water changes but very little with respect to these constituents. It follows from the equation that if percolation continues uninterrupted, the concentration of the percolate, so far as it is determined by an absorbed constituent, must get less and less until it becomes a vanishing quantity. This state of affairs does not exist in the soil, however, for percolation by pure water does not continue uninterrupted for any length of time. The rise of the capillary water in the soil will, under normal conditions, enable the soil to reabsorb more of the ordinary mineral constituents than is removed by percolating waters. Further attention will be given the matter in another chapter.

Another but quite different line of evidence as to the probable concentration of the soil solution is furnished by the 
investigation of the solubility of certain phosphates. ${ }^{1}$ It is popularly supposed that when superphosphate containing mono-calcium phosphate $\mathrm{CaH}_{4}\left(\mathrm{PO}_{4}\right)_{2} \cdot \mathrm{H}_{2} \mathrm{O}$ is added to a soil there is a more or less permanent increase of readily soluble phosphoric acid in the soil, although a part "inverts" to the somewhat less soluble dicalcium phosphate $\mathrm{CaH}\left(\mathrm{PO}_{4}\right) \cdot 2 \mathrm{H}_{2} \mathrm{O}$. Such probably is far from a correct view of what actually takes place. The results obtained by studying the solubility of the different lime phosphates in water at ordinary temperature $\left(25^{\circ} \mathrm{C}\right)$ can be expressed in a diagram similar to the accompanying sketch, which is much distorted for convenience in lettering. As the diagram indicates, when the concentration of the solution increases with respect to phos-

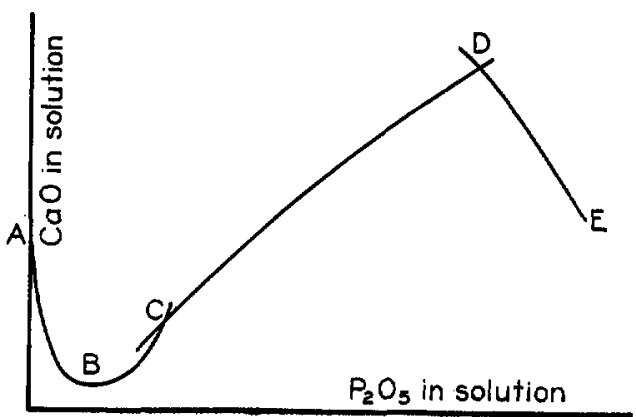

Fig. 2.- Solubility isotherm at $25^{\circ} \mathrm{C}$ for lime in aqueous solutions of phosphoric acid. Time point $A$ is realized in a few minutes, but it requires days or even months to reach complete saturation at $\mathrm{B}$.

phoric acid, the lime is at first less and less soluble until the point represented by $B$ is reached, then becomes more and more soluble until the point $D$ is reached, from then on becoming less and less soluble, until the solution reaches a syrupy consistency. In contact with all solutions represented by points on the line $D E$ the stable solid substance which can exist is mono-calcium phosphate, $\mathrm{CaH}_{4}\left(\mathrm{PO}_{4}\right)_{2} \cdot \mathrm{H}_{2} \mathrm{O}$. Along the line $C D$ the only solid which is stable and can continue to

1 For reference to the literature and detailed discussion see: The action of water and aqueous solutions upon soil phosphates, by F. K. Cameron and J. M. Bell, Bull. No. 4I, Bureau of Soils, U. S. Dept. Agriculture, 1907. 
persist is the dicalcium phosphate. From the point $C$ the composition of the stable solid varies continuously with the concentration of the liquid solution. Therefore, these solids form a series varying in composition from pure dicalcium phosphate to pure calcium hydroxide. One of these basic phosphates, as they would ordinarily be called, has a less solubility than any other, as indicated by the point $B$. All solutions to the right of the point $B$ have an acid reaction, while all solutions to the left possess an alkaline reaction. It follows from these facts that if we start with any lime phosphate corresponding to some point to the right of $B$ and dilute it, or what amounts to the same thing in case it has been added to the soil, if we leach it, phosphoric acid will go into solution more rapidly than will lime until the composition of the residue is that of the basic phosphate stable at $B$. Similarly, if we start with a phosphate more basic, lime will be removed more rapidly than phosphoric acid, until the residue has the composition of the phosphate of lowest solubility. From this point, with continued leaching, the lime and phosphoric acid will dissolve in a definite ratio, which ratio is obviously that of the phosphate of least solubility. That is to say, if the leaching process is slow, as would be the case under soil conditions, the solution would have a perfectly definite concentration with respect to lime and phosphoric acid. What the ratio of lime to phosphoric acid may be, is of no particular interest in this connection, but the order of concentration of phosphoric acid is of interest. Owing to serious analytical difficulties, this has not yet been determined with any great precision, but by interpolating on the experimentally determined curve $A C$, this concentration is found to be somewhere in the neighborhood of 5-ro parts per million, figures close to those obtained for the concentration of the soil solution with respect to phosphoric acid by the previously described investigations.

Under ordinary circumstances, however, it is not probable that lime is the dominant base controlling the concentration of phosphoric acid in the soil solution, since the great majority 
of agricultural soils contain vastly more ferric oxide (more or less hydrated) than is equivalent to any amount of phosphoric acid that will ever be brought into the soil; and ferric phosphates are less soluble relatively than lime phosphates. Investigation of the relation of ferric oxide to solutions of phosphoric acid shows that the system is quite similar in many respects to the basic lime phosphates and water just described. When the ratio of iron to phosphoric acid in the solid is greater than that required by the formula of the norma phosphate, $\mathrm{FePO}_{4}$; the aqueous solution will have an acid reaction and contain a mere trace of iron and an amount of phosphoric acid determined by the composition of the solid and by the proportion of solid to water. The basic ferric phosphates seem to be solid solutions which yield a very dilute aqueous solution when brought into contact with water. What the concentration will be under soil conditions is shown by the percolation experiments cited above.

The addition of other substances will in many cases affect more or less the solubility of the soil minerals. If these substances be electrolytes, they will generally, but not always, affect the solubility of the minerals as would be anticipated from the hypothesis of electrolytic dissociation. Thus, the addition of potassium sulphate lessens the solubility and hydrolysis of a potash feldspar or a potash mica. Contrary, however, to the indications of the hypothesis, sodium nitrate decreases the solubility of a ferric phosphate. While appreciable solubility effects take place with sufficiently high concentrations, laboratory experiments indicate that the addition of such substances, even in a liberal application of fertilizers, is not sufficient to produce any great effect on the concentration of the soil solution. Similarly, it has often been supposed that the ammonia, and nitrous and nitric oxides of the atmosphere carried into the soil by rain, or formed in the soil by bacterial action, affect the solubility of the soil minerals, but it is highly improbable that the concentration with respect to these agents ever becomes sufficiently high, as laboratory investigations show to be necessary 
to affect appreciably the solubility of the ordinary rock-or soil-forming minerals.

Rain brings from the atmosphere into the soil two agents, however, which do markedly affect the solubility of the soil minerals, namely, oxygen and carbon dioxide. The atmosphere within the soil contains normally a somewhat smaller proportion of oxygen than does the air above the soil. Rain in falling through the air absorbs or dissolves relatively more oxygen than nitrogen. Therefore when the rain water has penetrated the soil to any considerable depth there should be, and probably is, a liberation of dissolved oxygen into the atmosphere of the soil interstices. This dissolved oxygen in becoming liberated or when dissolved in the film water appears to be especially active towards the ferrous or ferro-magnesian silicates. These minerals are, moreover, as a class probably the most soluble of the rock-forming silicates. Consequently oxygen brought into the soil in this manner is one of the most important agencies in breaking down and decomposing such minerals as the amphiboles, pyroxenes, chlorites, certain serpentines, phlogopites and biotites; at the same time there is formed ferric oxide (more or less hydrated) and silica (probably as quartz) and magnesium, potassium, calcium or sodium pass into solution, probably as bicarbonates. That the concentration of the soil moisture may thus be made temporarily abnormal is not impossible, though scarcely probable.

The soil atmosphere has normally a decidedly higher content of carbon dioxide than the atmosphere above the soil. Consequently the soil water is always more or less "charged" with carbon dioxide, and the presence of the carbon dioxide decidedly augments the solvent powers of the water towards a great many and different kinds of rockforming or soil minerals. What the mechanism of the reaction may be is far from clear. The obvious explanation, at least in the case of the ordinary silicates of the alkalis or alkaline earths, is that by forming bicarbonates of the hydrolyzed bases, the active mass of the reaction product with 
water is decreased and hydrolysis thereby increased. But this explanation is apparently insufficient to account for the effects sometimes observed. It has been shown that the passage of carbon dioxide through solutions of the silicates, will produce more or less slowly a precipitation of silica, and there seems little reason to doubt that it does induce to some degree a decomposition and consequent greater solubility of the silicates of the alkalis and alkaline earths. It also increases to an appreciable extent the solubility of the phosphates of iron, alumina, and lime. Therefore, the variation in the content of carbon dioxide in different soils, and its continual variation from time to time in any one soil, must be expected to produce corresponding changes in the soil solution with respect to such bases as potassium and lime, and also with respect to phosphoric acid. This has been verified experimentally by aqueous extracts of soils, the solutions being charged with carbon dioxide while in contact with the soils. $^{1}$ It is not conceivable, however, that any great difference can exist in the partial pressures of carbon dioxide in different soils which are in a condition to support crops, and therefore great absolute differences in the mineral content of the soil solution are not to be anticipated, nor are they actually observed.

It has long been held that the organic substances in the soil have an important solvent effect on the minerals. This assumption seems quite unwarranted in the light of 'our present knowledge, although it is not to be denied that occasionally there may be present in the soil some soluble organic substance which influences the mineral content. Generally it has been assumed that the effective organic substances influencing the solubility of the minerals are organic acids, of which a number have found their way into past and even current literature, and which have been designated as humic, ulmic, crenic, apocrenic, azohumic acids, etc. Their

${ }^{1}$ See, for instance, the results obtained by Peter, Proceedings of the Igth Annual Convention of the Association of American Agricultural Colleges and Experiment Stations, Bull. No. I64, Office of Experiment Stations, U. S. Dept. Agriculture, 1906, p. I5 I et seq. 
existence is purely hypothetical and without experimental or other scientific verification, and calls for no further consideration here.

It is a widespread and popular notion that substances with a slight solubility also dissolve slowly, and that consequently the solubility of the minerals in the soil water must necessarily be a very slow process. This is, however, a misapprehension. It has been shown with a number of the common rock-forming minerals, that if they be powdered and then stirred into a relatively small volume of water, they dissolve very rapidly at first, and in a very short time, generally a few minutes, the solution is nearly saturated with respect to the mineral. Complete saturation, however, may require many days. The general shape of curve expressing the rate of solubility is shown in the accompanying figure. ${ }^{1}$ For soils,

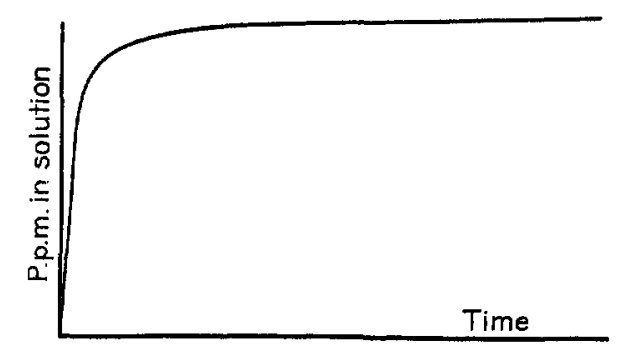

Fig. 3-Rate of solution of powdered ninerals.

this fact has been verified repeatedly, in the following way: a cell fitted with parallel electrodes is placed in circuit with a slide-wire ${ }^{2}$ or Wheatstone bridge in such a manner that the resistance of the cell contents can be quickly determined. Distilled water is then placed in the cell and its resistance found. Crenerally this will be upwards of roo,ooo ohms. The soil or rock powder under examination is then added to the cell, being rapidly stirred into the water contained therein.

\footnotetext{
${ }^{1}$ See, for example, Umwandlung des Feldspats in Sericit (Kaliglimmer) von Carl Benedick, Bull. Geol. Inst. Upsala, 7, 278-286 (I904).

${ }^{2}$ See Electrical instruments for determining the moisture, temperature and soluble salt content of soils, by L. J. Briggs, Bull. No. I5, Bureau of Soils, U. S. Dept. Agriculture, I 899 .
} 
The resistance drops to about 5,000 ohms within a short space of time usually three or four minutes. A further slight drop in the resistance generally takes place, but it requires days, and sometimes even months to become nore than barely appreciable. In this manner it has been shown that the soil and many of the common soil minerals dissolve quite rapidly if they are sufficiently fine to offer a large surface to the action of the water. It would seem to follow, therefore, that in the case of the soil solution the concentration with respect to these constituents derived from the soil minerals, will be rapidly restored whenever disturbed through absorption by plants, leaching, or otherwise.

That the minerals of the soil, or a powdered mineral or rock-powder, will dissolve continually as the concentration of the solution in contact with it is disturbed by abstraction of a dissólved mineral substance, has been shown by numerous experimenters. An apparently obvious way to test this point would be to treat the soil sample with successive portions of water, and to analyze the successive portions for the dissolved mineral substances. This method, however, involves serious experimental difficulties, owing to the smaller sized mineral particles being suspended in the mother liquor, thus precluding satisfactory decantation and clogging filters. Moreover, such a process in no case simulates field conditions. To meet these difficulties, the soil or mineral powder has been placed between two porous media, as in the space between two concentric cylinders of unglazed porcelain, the space being closed by a rubber stopper. To the interior cylinder is fitted a stopper carrying a tube of insoluble metal, such as platinum or tin. This tube is bent into a goose-neck form, and just below the stopper the tube is perforated with a small opening. The whole apparatus is filled with water and set in a beaker, also filled with water. The metal tube is made the cathode in an electric circuit, a platinum or other suitable anode being introduced into the beaker. In a few minutes the dissolved and hydrolyzed bases pass into the cathode chamber, and as the water also accumulates in the chamber by electrolytic endosmosis, a solution of the bases 
dissolved from the soil minerals drops from the end of the metal goose-neck. By adding water to the outer beaker from time to time, a steady stream of alkaline solution has been obtained for months, and in no case yet has a soil thus treated failed to continue to yield up the bases it contains in its mineral particles. The acids, such as phosphoric acid for example, are of course found in the water outside the porous cells, and in the case of the phosphoric acid it also appears to continue indefinitely to be withdrawn from the soil. ${ }^{1}$ It thus appears that as the products of solution and hydrolysis are removed, by such an endosmotic device as that just described or by the roots of growing plants, by leaching or otherwise, the soil minerals will continue to dissolve.

The foregoing arguments as to the concentration of the soil solution with respect to those constituents derived from the soil minerals, are based on the generally recognized principle that a material system left to itself tends towards a condition of stable equilibrium or final rest, that is, a condition where such changes as are taking place are so balanced that no change occurs in the system as a whole. But the soil is a system continually subject to outside forces and influences, and as pointed out above, is of necessity a dynamic system. It is doubtful in the extreme if any soil in place is ever in a state of final stable equilibrium. It would be natural, therefore, to expect and to find that even if the solution in the soil were directly dependent on the solubility of the soil minerals alone and were continually tending towards a definite normal concentration, actually this concentration would seldom if ever be realized. Most important in this connection is the fact that the concentration of the soil solution is always dependent in some degree upon the concentration of the soluble constituents in the solid phases in other than definite chemical combinations. Nevertheless, the evidence at hand indicates that the various processes taking place in the soil as a whole continually tend to form and maintain a normal concentration of mineral constituents in the soil solution.

${ }^{1}$ For detailed description of the apparatus and experimental data, see Bull. No. 30, p. 27, et seq., Bureau of Soils, U. S. Dept. Agriculture, I905. 